\title{
El octavo espejo: Las Meninas en el despacho de verano del Alcázar de Madrid
}

\section{The eighth mirror: the Meninas in the King's summer study in the Alcazar of Madrid}

\author{
Juan María Cruz Yábar \\ Museo Arqueológico Nacional
}

Fecha de recepción: 31 de octubre de 2016

Fecha de aceptación: 18 de junio de 2017

\author{
Anuario del Departamento de Historia y Teoría del Arte \\ vol. 29-30, 2017-2018, pp. 169-190 \\ IISSN: 1130-5517, eISSN: 2530-3562
}

http://doi.org/10.15366/anuario2017-2018.29-30.07

\begin{abstract}
RESUMEN
Tras aportar nuestra visión a partir de Palomino y de algunos debates doctrinales en torno a las Meninas, proponemos una nueva interpretación del cuadro a partir de su ubicación original, el despacho de verano de Felipe IV en el Alcázar de Madrid. Reconstruimos este espacio con sus espejos, bufetes y pinturas y desvelamos un programa iconográfico alegórico en él, pero sobre todo los ingeniosos juegos visuales que tenían lugar entre esos elementos de adorno y el lienzo, que hacía función de octavo espejo de la estancia.
\end{abstract}

\section{PALABRAS CLAVE}

Felipe IV. Infanta Margarita. Velázquez. Despacho de verano del Alcázar. Espejos. Bufetes. Pinturas.

\begin{abstract}
After contributing with our vision based on Palomino and some doctrinal debates about the Meninas, we propose a new interpretation of the painting from its original location, Philip IV's summer study in the Alcazar of Madrid. We reconstruct this space with its mirrors, writing desks and paintings and we reveal an iconographic program in it, but above all the ingenious visual plays which took place between these ornamental elements and the canvas, which served as the eighth mirror of the room.
\end{abstract}

\section{KEY WORDS}

Philip IV. Infanta Margarita. Velazquez. Summer study in the Alcazar. Mirrors. Writing desks. Paintings.

El óleo sobre lienzo de Velázquez llamado popularmente las Meninas (fig. 1), una de las pinturas más importantes de todos los tiempos, se ha visto envuelto en los más diversos interrogantes, que giran en torno a aspectos técnicos sobre el modo en que el pintor llevó a su lienzo el Cuarto del Príncipe que le sirvió de escenario y a cuestiones que atañen al trasfondo ideológico de la pintura ${ }^{1}$. En la primera parte de este tra-

\footnotetext{
1 Ante la lógica imposibilidad de citar la enorme cantidad de referencias bibliográficas relativas a las Meninas por falta de espacio, remitimos a la completa recopilación en la ficha del cuadro de la colección del Museo del Prado (https://www.museodelprado.es/
} 


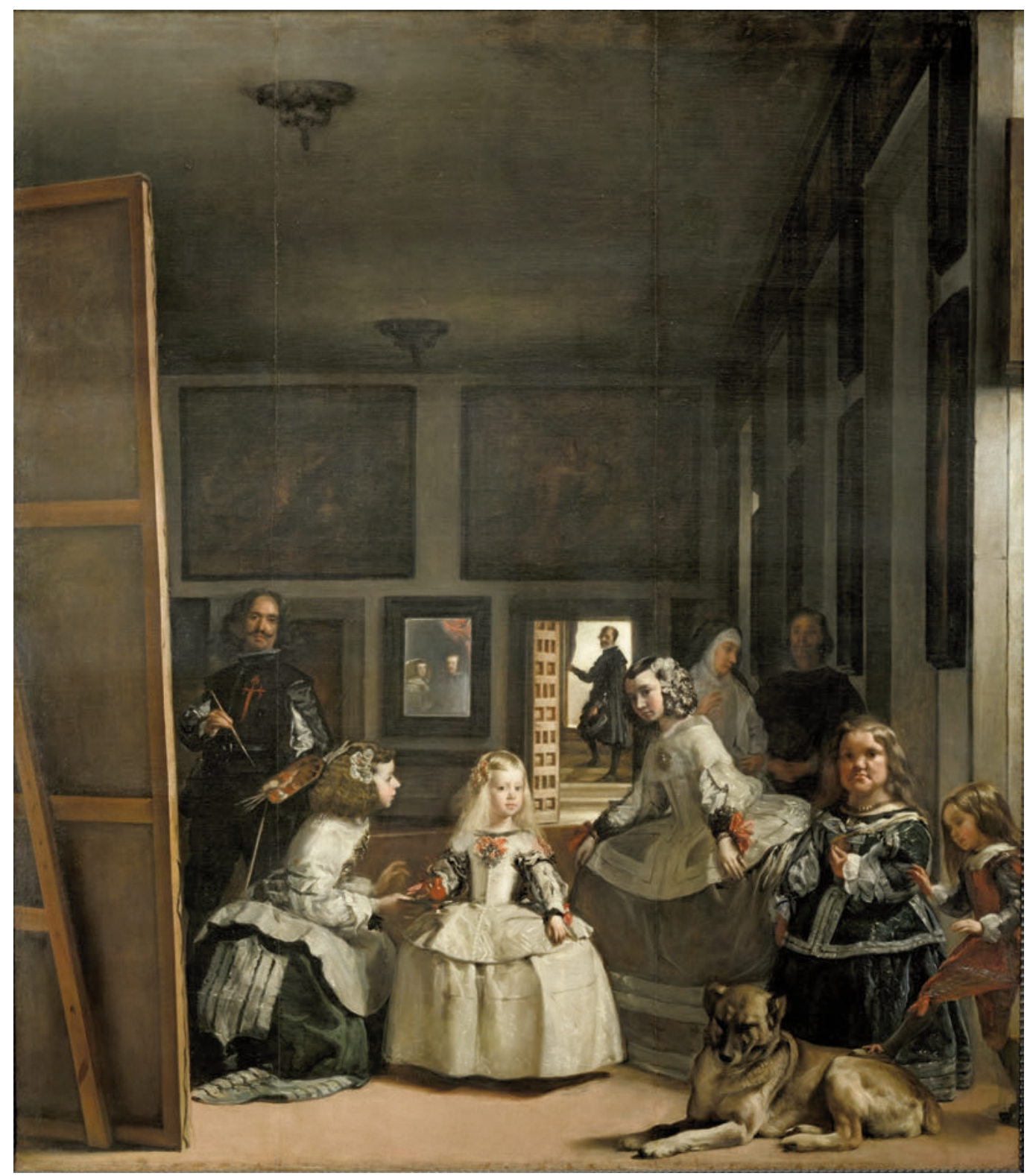

Fig. 1. Diego Velázquez, las Meninas, 1656, óleo sobre lienzo. 318 x 276 cm, Madrid, Museo Nacional del Prado, P01174.

bajo recordamos los fundamentos de todas ellas, los textos de Palomino, que no han perdido su validez a pesar del paso del tiempo, y hacemos algunas observaciones personales que son claves para las tesis que sostenemos más adelante. En la segunda parte se encuentra nuestra principal aportación: los interrogantes que surgen en torno al significado de esta pintura como centro de la decoración inventada por Velázquez para la pieza a la que destinaba la obra, el Despacho de verano del rey en el Alcázar de Madrid, junto a una hipótesis de su reconstrucción. 


\section{El interior del cuadro: el Cuarto del Príncipe}

La primera y más fiable fuente de noticias sobre las Meninas es el tratado de pintura de Palomino² que contiene la biografía antigua más completa de Velázquez, especialmente atenta al lienzo que Juan Bautista Martínez del Mazo describió en 1666 como retrato de "la señora Emperatriz con sus damas y una enana"3.

El relato de Palomino constituye una interpretación casi auténtica y merece prestarle atención, a modo de una vuelta a los orígenes. El tratadista obtuvo testimonios orales de sus maestros Juan de Alfaro y Juan Carreño de Miranda $^{4}$, vinculados a Velázquez en sus últimos años de vida, cuando el pintor daba forma al cuadro $^{5}$. Él mismo reconoció que la biografía del genial pintor la había redactado en su mayor parte Alfaro y que él la incluyó y aumentó en su libro ${ }^{6}$. Confirma lo primero el hecho de que haya frases coincidentes en el pasaje de las Meninas y en el que Alfaro dedica al Lavatorio de Tintoretto y otros cuadros en la Memoria 7 que escribió al dictado de Velázquez después de 1656 y antes de 1660 para la disposición de las pinturas en la sacristía y otras partes del monasterio de El Escorial ${ }^{8}$. También queda probado que Palomino adicionó y modificó el manuscrito de Alfaro sobre las Meninas, así su párrafo sobre Lucas Jordán, llegado a España más de treinta años después de fallecido Velázquez, y la anécdota de la cruz de Santiago ${ }^{9}$, pues tras escribir "que después de muerto le mandó Su Majestad se le pintasen", que ha de ser lo que le dijo Alfaro ${ }^{10}$, rectifica y escribe: "y algunos dicen, que Su Majestad mismo se lo pintó para aliento de los profesores de esta nobilísima arte, con tan superior cronista”. Fiel a su línea, Palomino desfiguró una vez más los hechos para dar mayor relevancia social a los pintores y a su arte, un sesgo que resta credibilidad a alguno de sus testimonios.

Palomino identifica la pieza que sirvió de fondo al retrato de la infanta y cortesanos que la rodeaban. Es bien sabido que el Cuarto del Príncipe estaba en la planta baja del palacio con aberturas a la fachada

\footnotetext{
2 Antonio Palomino, Museo Pictórico y Escala Óptica, Madrid, 1715-1724 (ed. Aguilar, 1947), pp. 920-922.

3 Transcrito por Gloria Martínez Leiva y Ángel Rodríguez Rebollo, El inventario del Alcázar de Madrid de 1666: Felipe IV y su colección artística, Madrid, CSIC-Polifemo, 2015 (en adelante Inv. 1666). Se ignora el motivo por el que Mazo omitió que su suegro aparecía en el cuadro. En los inventarios del Alcázar de 1686 (en adelante Inv. 1686), transcrito por Yves BotTinEAU, "L'Alcázar de Madrid et l'inventaire de 1686. Aspects de la cour d'Espagne au XVIIe siècle", Bulletin Hispanique, t. 60, n 1, pp. 30-61, n 3, pp. 289-326, y de 1701, transcrito por Gloria FERnÁNDEZ BAYTON, Inventarios Reales. Testamentaría del rey Carlos II, 1701-1703, t. I (Inv. 1701), la partida recordaba tan apreciable hecho: "retratada la señora Emperatriz, infanta de España, con sus damas y criados y una enana, original de Diego Belázquez, pintor de cámara y aposentador de palacio, donde se retrató a sí mismo pintando".

4 "Alfaro [...] dejó algunos apuntamientos de la vida de Velázquez, su maestro [...] que nos han sido de mucha utilidad para este tratado" y "otras cosas, que oí a Carreño, y a otros antiguos".

5 Lo acabó en 1656, según consta en el texto y también que retrató a Margarita "siendo de muy poca edad" (había nacido el 12 de julio de 1651, tendría cuatro o cinco años).

6 "Consagróle el siguiente epitafio, y le hizo imprimir su muy caro, e ingenioso discípulo Don Juan de Alfaro, insigne cordobés (a quien se debe lo más principal de esta historia)".

7 Juan de Alfaro (copia), Memoria de las pinturas que la magestad cathólica del rey nuestro señor don Phelipe IV embía al monasterio de San Laurencio el Real del Escorial, este año de MDCLVI, descriptas y colocadas por Diego de Sylva Velázquez...Madrid, 1656-1660. Han surgido dudas entre los historiadores sobre la autoría de Alfaro en la memoria referida a El Escorial, pero la coincidencia de pasajes y la seguridad de su autoría en el texto copiado por Palomino prueban la del escrito escurialense. Sobre la memoria vid. Fernando MARÍAS, "Los saberes de Velázquez: el lenguaje artístico del pintor y el problema de la 'Memoria de las pinturas del Escorial', en Symposium Internacional Velázquez, Sevilla, Junta de Andalucía, 2004, pp. 167-177, y Bonaventura BASSEgODA I HugAS, Velázquez y la decoración pictórica de El Escorial en 1656", en Symposium Internacional Velázquez, Sevilla, Junta de Andalucía, 2004, pp. 311-328.

8 José Manuel Cruz Valdovinos, Velázquez, Vida y obra de un pintor cortesano, Zaragoza, Caja Inmaculada, 2011, p. 331. "Dificultosamente se persuade el que la mira a que es pintura: tal es la fuerza de sus tintas y disposición de su perspectiva, que juzga poderse entrar por él y caminar por su pavimento enlosado de piedras de diferentes colores que, disminuyéndose, hacen parecer grande la distancia en la pieza y que entre las figuras hay aire ambiente". Vid. la comparación con el texto de las Meninas que ofrecemos más adelante.

${ }^{9}$ Hábito concedido a Velázquez en noviembre de 1659, por lo que la pintura de la cruz en su autorretrato tuvo que ser posterior.

10 Se piensa con razón que fue Juan Bautista Martínez del Mazo, yerno del pintor, quien pintó la cruz por orden del rey.
} 
principal. Medía casi 70 x 20 pies (19,60 x 5,60 m). En los lados cortos había dos puertas en cada uno de los extremos. La del oeste, inmediata a la fachada -no visible en la pintura- daba acceso a la Torre del Rey, mientras que la otra conducía al piso superior a través de la escalera del Rubinejo, que se observa al fondo de la pintura iluminada por una ventana. La pared que queda a la derecha, correspondiente a la fachada del Palacio, tenía siete ventanas. Velázquez pintó cinco; la primera y la quinta dejan entrar la luz al tener los postigos abiertos y en las tres intermedias están cerrados. El tramo correspondiente a las dos primeras ventanas queda fuera del cuadro. El fondo real de lo pintado, por tanto, podía estar en torno a unos 15 metros de profundidad.

El tratado ponderó la obra: "y en fin, no hay encarecimiento, que iguale a el gusto, y diligencia de esta obra; porque es verdad, no pintura". Esta última expresión alude al realismo que transpira el cuadro, casi una instantánea fotográfica, como han resaltado muchos autores. Pero también llama la atención sobre la manipulación de esa realidad. Velázquez desfigura en primer lugar el espacio, engrandeciéndolo. La biografía apunta: "Tiene esta galería varias ventanas, que se ven en disminución, que hacen parecer grande la distancia [...] El pavimento es liso, y con tal perspectiva, que parece se pueda caminar por él: y en el techo se descubre la misma cantidad".

Velázquez demostró su dominio de la perspectiva geométrica, pero sobre todo la aérea, destacada por Alfaro: "entre las figuras hay ambiente". Comenta la fuente los riquísimos matices del tratamiento lumínico: "es la luz izquierda, que entra por ellas, y solo por las principales y últimas", "[Pertusato] esta figura es oscura y principal", "en término más distante, y en media tinta, está doña Marcela de Ulloa", "[Nieto] muy parecido, no obstante la distancia, y degradación de cantidad, y luz, en que se supone". La luz derramada a través de la primera y quinta ventana destaca a las personas reales frente a los criados, que quedan en penumbra o de perfil.

Asunto muy discutido ha sido la acción representada. El texto de Palomino identificó a todos los personajes que componen la escena, menos uno, y comentó algunas acciones, empezando por la infanta, de tierna edad:

Faltan palabras para explicar su mucha gracia, viveza y hermosura; pero su mismo retrato es el mejor panegírico. A sus pies está de rodillas Doña María Agustina, menina de la Reina, hija de Don Diego Sarmiento, administrándole agua en un búcaro. Al otro lado está Doña Isabel de Velasco (hija de Don Bernardino López de Ayala y Velasco, Conde de Fuensalida, Gentilhombre de cámara de Su Majestad) menina también y después dama, con un movimiento, y acción propicísima de hablar. En principal término está un perro echado, y junto a él Nicolasico Pertusato, enano, pisándolo, para explicar a el mismo tiempo, que su ferocidad en la figura, lo doméstico, y manso en el sufrimiento; pues cuando le retrataban se quedaba inmóvil en la acción, que le ponían; esta figura es oscura y principal. Detrás está Mari Bárbola, enana de aspecto formidable; en término más distante, y en media tinta, está Doña Marcela de Ulloa, señora de honor, y un guardadamas, que hacen a lo historiado maravilloso efecto. A el otro lado están Don Diego Velázquez pintando: tiene la tabla de colores en la mano siniestra, y en la diestra el pincel, la llave de la cámara, y de Aposentador en la cinta y en el pecho el hábito de Santiago [...] A el lado izquierdo del espejo está una puerta abierta, que sale a una escalera, en la cual está José Nieto, Aposentador de la Reina, muy parecido.

Las diferencias interpretativas se centraron preferentemente en la pareja real, si acababa de entrar o llevaba allí algún tiempo, si había acudido para posar o para ver pintar a Velázquez ${ }^{11}$. Palomino escribió:

11 Vid. por ejemplo Jonathan BRown, "Sobre el significado de las Meninas. Postscriptum”, en Otras Meninas, Madrid, Siruela, 1995, pp. 67-91. Para la visita del gobernante al artífice y otros tópicos de su relación, Juan Miguel SERRERA, "El palacio como taller y el taller como palacio. Una reflexión más sobre Las Meninas", en Madrid en el contexto de lo hispánico desde la época de los descubrimientos, vol. I, Madrid, Universidad Complutense, 1994, pp. 231-246. Otros interesantes comentarios al respecto y de la relación con el teatro en Javier PoRTús PÉREz, "Diego Velázquez, 1650-1660. Retrato y cultura cortesana", en Velázquez y la familia de Felipe IV, Madrid, Museo Nacional del Prado, pp. 17-60, espec. 47-49. 
"Esta pintura fue de Su Magestad muy estimada, y en tanto que se hacía, asistió frecuentemente a verla pintar; y asimismo la Reina nuestra señora Doña María Ana de Austria bajaba muchas veces, y las señoras infantas y damas, estimándolo por agradable deleite, y entretenimiento". El tratadista nunca afirmó la presencia de Felipe y Mariana en la habitación. Pero si aceptamos que Nieto está allí porque están los reyes, a los que precedía como aposentador, es lógico que se plantee el problema, tanto más si varios personajes miran al frente y parece que están sorprendidos por su repentina entrada. Opinamos que Palomino una vez más acertó al insinuar que el motivo de la presencia de los soberanos era ver pintar a Velázquez. Los retratos reales se hacían tomando el pintor breves apuntes para un modelo de la cabeza, y la elaboración de la versión definitiva se hacía en el obrador. Esta conclusión no prejuzga nada sobre el asunto que estaba pintando Velázquez.

¿Qué es lo que refleja el espejo? ¿Es la imagen real de los reyes al entrar en la habitación o es el doble retrato real? La respuesta está también en Palomino que recogió lo que le contó Alfaro:

El lienzo en que está pintando es grande, y no se ve nada de lo pintado, porque se mira por la parte posterior, que arrima en el caballete. Dio muestra de su claro ingenio Velázquez en descubrir lo que pintaba con ingeniosa traza, valiéndose de la cristalina luz de un espejo, que pintó en lo último de la galería y frontero a el cuadro en el cual la reflexión o repercusión nos representa a nuestros Católicos reyes Felipe y María Ana.

Autores posteriores aceptaron que pintaba un retrato de los reyes ${ }^{12}$, pero Lafuente ${ }^{13}$ encontró que el lienzo era demasiado grande para un doble retrato. Poco después, du Gué Trapier ${ }^{14}$ sostuvo que Velázquez estaba pintando las propias Meninas ${ }^{15}$. Gerstenberg ${ }^{16}$ pensó que estaba retratando a la infanta. Estas dos últimas teorías exigirían, para ser posibles, un complicado juego de espejos que en la actualidad podría ser factible, pero no cuando se pintó este cuadro.

El texto de Palomino no deja lugar a dudas de que el espejo fue el artificio elegido por el pintor para que pudiera verse el anverso del bastidor del cuadro, pero su error estuvo en afirmar que era verdadero reflejo. Los autores se abalanzaron para discutir este punto con argumentos débiles desde nuestro punto de vista, tales como que no existe retrato real doble alguno del momento ni documentación al respecto, que los dobles retratos eran excepcionales en la pintura española y, sobre todo, que las figuras reales de cuerpo entero medían de alto unas dos varas y media y este lienzo tiene vara y cuarta más. No son terminantes estos argumentos, pues nada impide que pudiera hacerse un retrato doble aunque no fuera habitual, y las dimensiones del lienzo podrían justificarse por el gran cortinaje que se observa en el espejo por encima de las cabezas de los reyes ${ }^{17}$. El argumento que de verdad se opone a la afirmación de Palomino es que el espejo, desde el punto de vista frontal con que aparece representado el cuarto del príncipe, debía reflejar un fragmento central de la pared de enfrente. Según la estructura de la pieza, en ese punto no existía puerta ni por tanto cortina, lo que excluye que sea una imagen de los reyes entrando en la habitación. En cuanto a que fuera el anverso del lienzo y lo que se reflejara fuera la pintura, es igualmente imposible si tenemos en cuenta que el bastidor está algo torcido y que la anchura de la habitación $(5,60 \mathrm{~m})$ y la del bastidor $(2,76 \mathrm{~m})$ harían inevitable que se reflejara un costado del lienzo y no el centro, donde estarían los reyes en una hipotética pintura.

Por consiguiente, lo que muestra la imperfecta luna del fondo no es reflejo de una imagen verdadera, sino lo que el pintor desea que veamos, los reyes, y así hacer creer a los espectadores que los estaba pin-

12 Un resumen de las principales teorías en CRUZ VALDOVINOS, 2011, pp. 334-335.

13 Enrique Lafuente Ferrari, Velázquez, Londres, Phaidon Press, 1943, p. 30.

14 Elizabeth du GuÉ Trapier, Velázquez, Nueva York, 1948, p. 339.

15 Hipótesis presente ya en el catálogo del Prado de 1819.

16 Kurt Gerstenberg, Diego Velázquez, Berlín-Múnich, Deutscher Kunstverlag, 1957, p. 193.

17 Cruz Valdovinos, 2011, señala que el color y forma del cortinaje que se extiende sobre los reyes difiere del que ha descorrido Nieto y que se trata de una cortina de aparato, por lo que el pintor pudo fingir que llevaba a cabo un retrato de estas características. 
tando. Las reglas de la óptica o las de la lógica no debían ser obstáculo para que Velázquez pudiera dar forma a su idea.

De esa idea velazqueña formaba parte el escenario elegido para colocar sus personajes. Palomino avisa: "se ven varias pinturas por las paredes, aunque con poca claridad, conócese ser de Rubens, e historias de las Metamorfosis de Ovidio”, en realidad copias de Rubens y sus colaboradores por Mazo.

Velázquez tuvo gran interés en situar la escena en el Cuarto del Príncipe a causa de los dos cuadros que colgaban a cada lado del espejo, las copias de las fábulas de Palas y Aracne de Rubens (desaparecida, se conoce el boceto) y de Apolo y Marsias de Jordaens (Museo del Prado). Sabía que los habitantes del Palacio reconocerían los asuntos pese a su falta de nitidez ${ }^{18}$. Como desveló Tolnay ${ }^{19}$, significan el triunfo del arte sobre el oficio, porque Minerva y Apolo eran los patronos mitológicos de las artes y Aracne y Marsias, los derrotados, ejercían oficios. Los pintores, y de manera especial Velázquez, buscaban el reconocimiento de la pintura como arte liberal y ese cuadro había de ser el refrendo anhelado ${ }^{20}$.

El sevillano se autorretrató como pintor de cámara, el oficio más alto en la pintura, con tabla de colores, pinceles, tiento y lienzo, y en su ejercicio más elevado, retratar a los monarcas. A la vez muestra con orgullo su oficio palatino por medio de su vestimenta de caballero y la llave de ayuda de cámara y aposentador. Hace ver que la labor de pintar puede ejercerla "vestido con la capa", como solía señalarse por los abogados defensores de las causas de la ingenuidad de los artífices. El cuadro constituye un alegato de que el ejercicio de la pintura no debía impedir que vistiera un hábito de orden militar, como sucedió ${ }^{21}$ con el apoyo de Felipe IV. Ya Palomino se encargó de señalar estos aspectos:

Con no menos artificio considero este retrato de Velázquez que el de Fidias escultor y pintor famoso, que puso su retrato en el escudo de la estatua, que hizo de la diosa Minerva fabricándole con tal artificio, que si de allí se quitase, se deshiciese también de todo punto la estatua. No menos eterno hizo Ticiano su nombre, con haberse retratado teniendo en sus manos otro con la efigie del señor Rey Don Felipe Segundo; y así como el nombre de Fidias jamás se borró, en cuanto estuvo entera la estatua de Minerva, y el de Ticiano, en cuanto durase el del señor Felipe Segundo; así también el de Velázquez durará de unos siglos en otros, en cuanto durase el de la excelsa, cuanto preciosa Margarita; a cuya sombra inmortaliza su imagen con los benignos influjos de tal soberano dueño.

No contento con expresar en la pintura su mensaje, Velázquez lo prolongó en la habitación elegida para colocarla, el despacho de verano.

\section{El exterior del cuadro: el Despacho de Verano del Rey}

Frente a los extensos estudios a que ha dado lugar la propia pintura, la habitación donde fue colocada no ha sido apenas considerada como un hecho más a tomar en cuenta para la interpretación de la obra cumbre velazqueña ${ }^{22}$. Que sepamos, nadie se ha preguntado el sentido de la decisión del pintor de colocar en

\footnotetext{
18 Es extraño que Alfaro o Palomino no identificaran al menos los dos cuadros del fondo, claves para uno de los sentidos del interior de la pintura, la liberalidad de este arte. No se movieron de su lugar al menos hasta 1701, y probablemente tampoco hasta el incendio de 1734. Es posible que Apolo y Minerva aludieran a Felipe IV y Mariana, que están debajo; en la bóveda y en un bufete del despacho se identificaba a Felipe IV con Apolo, como veremos.

19 Charles de TolnaY, "Velázquez, Las Hilanderas y Las Meninas (An Interpretation)", Gazette des Beaux Arts, XXXV (1949), pp. 21-38.

20 Sobre esta cuestión de la nobleza de la pintura en las Meninas vid. BROwn, 1995, pp. 68-76 y CRUZ VALDOVINOS, 2011 , pp. $335-336$.

21 "Y en el pecho el hábito de Santiago [...] porque cuando pintó Velázquez este cuadro, no le había hecho el Rey esta merced".

${ }^{22}$ El único autor que ha dedicado atención a la pieza donde colocaron a las Meninas y al mobiliario que rodeó al cuadro ha sido Fernando MARÍAs, El género de las Meninas. Los servicios de la familia, en VV.AA., Otras Meninas, Madrid, Siruela, 1995, 
el despacho de verano una pintura tan peculiar en medio de un escenario que dispuso, sin duda, con todo cuidado.

El despacho de verano estaba situado en el llamado Cuarto Bajo de Verano, una serie de habitaciones situadas en la planta sobre las bóvedas de la crujía nordeste del palacio y en un pequeño cuerpo edificado en ángulo recto con la pared exterior de esta crujía. Este cuarto se conocía como "nuevo" en tiempos de Felipe II, que debió ordenar su construcción para alojar a los Consejos. Cumplía aún esta función en 1626, pues el plano del Alcázar de Juan Gómez de Mora localiza en su planta baja tres tribunales ${ }^{23}$.

El terreno en que estaba edificado el Alcázar descendía considerablemente hacia el norte, de modo que "la planta baja al andar de los patios" quedaba a una gran altura sobre el terreno en el ala oriental y más aún en la del norte que caía al jardín de la Priora, donde estaba el cuarto nuevo, la parte más fresca del palacio. En 1623 se estaba acondicionando en la parte de las bóvedas del cuarto nuevo unos espacios destinados a habitaciones reales que se conocerían como "cuarto bajo de verano", con seis piezas al menos, y “bóvedas de verano", aún más abajo ${ }^{24}$. Entre 1632 y 1633 se hizo una ampliación de ambas plantas.

La ausencia de planos o imágenes obliga a hacer conjeturas sobre la distribución y forma de habitaciones del cuarto y bóvedas de verano basadas en los sucesivos inventarios del Alcázar de 1636, 1666, 1686 y 1701. En el inventario de 1636, tras bajar la escalera que conducía desde la Galería del Cierzo a las Bóvedas de Verano, que quedaba en el interior del cuarto nuevo, se inicia el recorrido por la pieza en que su majestad negocia, esto es, el despacho. Por ser la primera que se inventaría, se hallaría al lado de esa escalera y debía ocupar, por tanto, el extremo oriental del cuarto nuevo, con fachadas al cierzo y a levante. El recorrido siguió por las otras dos piezas consecutivas del cuarto nuevo, el Antedespacho y la pieza donde comía el rey, y desde allí se pasó a las otras tres piezas situadas en el cuarto antiguo o crujía norte del palacio, que eran una pieza larga donde cenaba el rey, su Dormitorio y el lugar donde leía, que era la última, ya dentro de la Torre Bahona ${ }^{25}$. En las bóvedas se identifica en 1666 una pieza que caía debajo del despacho de verano, acompañada de otra descrita en 1636 como la última de las bóvedas que mira al cierzo con una puerta ventana sobre el balcón para las fiestas, lo que confirmaría la situación propuesta.

Barbeito ha supuesto con fundamento que los muros de carga eran los mismos en el cuarto bajo de verano que los que aparecen con tal carácter en la planta de los tribunales y consejos, según el plano de Gómez de Mora $^{26}$. Disponemos de un testimonio gráfico del exterior del Alcázar en su lado norte ${ }^{27}$, que suele datarse en el reinado de Carlos II. El cuarto nuevo aparece reproducido frontalmente, por lo que solo se ve la pared al cierzo, y en la parte inferior se observa una ventana en línea con las de las dos plantas de arriba, que ha de corresponder al despacho de verano. El dibujo no informa sobre los laterales. La uniformidad de estas ventanas es un hecho favorable a la propuesta de que su superficie fuera semejante a la de la Sala del Crimen que quedaba encima. Según el pitipié de Gómez de Mora, esta sala medía poco más de 32 pies de largo $(9 \mathrm{~m})$ y 29 de ancho $(8,15 \mathrm{~m})$. Tenía una puerta que abría al antedespacho de 2 varas $(1,67$ m) y otra que daba al pasillo de media vara más $(2,08 \mathrm{~m})$, y dos ventanas, una a levante y otra al cierzo, ambas de 10 pies de ancho $\left(2,78 \mathrm{~m}\right.$ ). Bajo estos presupuestos intentaremos la reconstrucción (figs. 2-5) ${ }^{28}$.

pp. 247-278, si bien con carácter descriptivo y no para realizar una interpretación de la propia pintura. En el momento de entrega de este trabajo hemos tenido noticia del estudio de Thierry Greub, "Der Platz des Bildes und der "Platz des Königs". Diego Velázquez "Las Meninas” im Sommer-Arbeitszimmer Philipps IV”, Zeitschrift für Kunstgeschichte, vol. 78, n 3-4 (2015), pp. 441-487, pero no compartimos su reconstrucción del Despacho ni su interpretación como programa político.

23 Biblioteca Apostólica Vaticana, Barberini, Lat. 4372.

24 José Manuel Barbeito, El Alcázar de Madrid, Madrid, COAM, 1992, p. 154.

25 MARÍAS, 1995, pp. 249-250, llega a conclusiones parecidas.

26 BARBeito, 1992, p. 156.

27 Museu Nacional d'Art de Catalunya, Gabinete de Dibujos y Grabados, no 506, reproducido en José Manuel BARBEITO, "Velázquez y la decoración escultórica del Alcázar”, en Velázquez. Esculturas para el Alcázar, Madrid, 2007, pp. 113-131, fig. 10.

28 Debo la parte técnica de las reconstrucciones a Enrique Sanz Monge. 


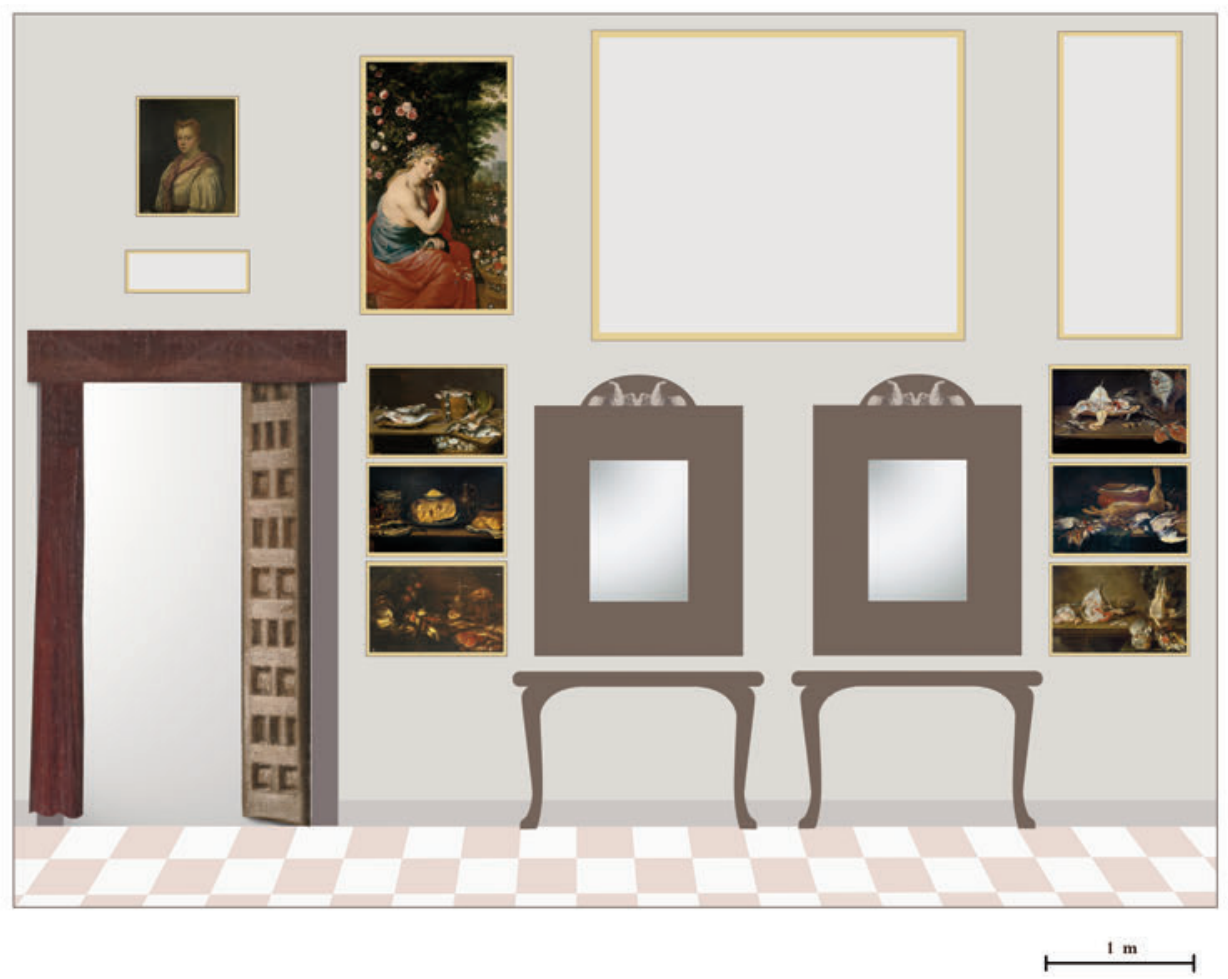

Fig. 2. Pared del antedespacho del despacho de verano en el Alcázar con las pinturas 111 (Reconstrucción del autor).

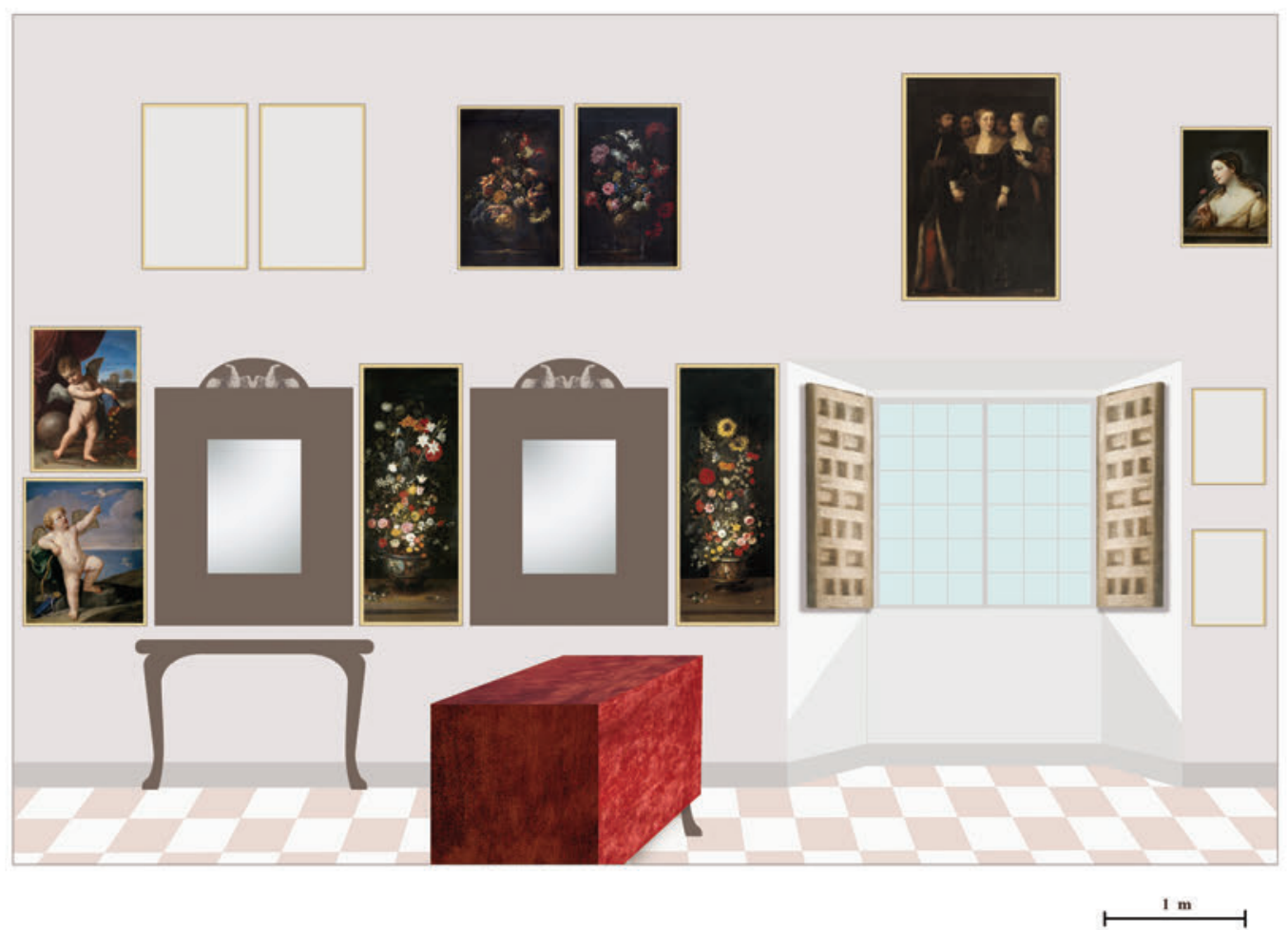

Fig. 3. Pared de levante del despacho de verano en el Alcázar con las pinturas 12-21 y 31-32 (Reconstrucción del autor). 
Frente al carácter público de la planta de los consejos y tribunales, es común afirmar que las dos plantas inferiores tenían carácter muy reservado. No obstante, señalamos que la privacidad era menos absoluta en el despacho y antedespacho, donde sería habitual la presencia de los secretarios reales y sus auxiliares y más ocasional la de personas muy notables de la administración, y en el cuarto de comer el rey solía recibir a visitantes ilustres, que asistían a su comida ${ }^{29}$. En especial, la pieza del despacho de verano debió ser relativamente conocida de los cortesanos de mayor rango, pues el rey pasaría bastantes horas en ella ${ }^{30}$.

En el cuarto de verano actuó Velázquez de forma muy intensa. La ocupación del sevillano en el adorno empezó hacia 1645, en que declaró el ayuda de la furriera Simón Rodríguez que las pinturas que tenía a su cargo habían quedado bajo la responsabilidad de Velázquez, incluidas las del aposento de verano "que las a mudado y trocado de unas partes a otras para poner de mejor orden" 31 . Las mudanzas del despacho de verano continuaron hasta el momento en que quedaron colocadas allí las Meninas.

Pieza importantísima en este programa lo constituían seis bufetes y siete espejos incluidos en el mobiliario, lo que recuerda al Salón de los Espejos como ya destacó Bottineau ${ }^{32}$. Había el mismo número de bufetes y el de espejos difería en uno solo, siete en el despacho y ocho del salón. Parecido era también el número de pinturas, 33 en el despacho y 31 en el salón según el inventario de 1686, aunque el tamaño medio de estas últimas era bastante más grande. Sorprende tal acumulación de muebles y pinturas en una pieza pequeña, pero podría explicarse porque el paramento solo estaba perforado por dos pequeñas puertas y dos ventanas, frente a las nueve y seis grandes del salón. En especial, las escasas dimensiones del despacho y la poca luz natural justificaban la conveniencia de tantos espejos, que no sólo aumentaban la claridad sino que ampliaban visualmente el espacio, a lo que contribuiría también la perspectiva profunda de las Meninas y el fresco pintado en el techo.

Fijaremos nuestra atención primero en los trece muebles, cuya descripción consta con detalle en los inventarios. En 1666 se citan las mesas ${ }^{33}$ como

Seis bufetes de pasta embutidos con sus pies digo de mármol de Jénova los tableros de bara bien cumplida de ancho y dos baras de largo y bara y quarta de alto con sus pies de ébano y bronzes dorados y en las pilastras y frisos de las cornisas sus embutidos de jaspe de colores de pasta y los tableros de mármol embutidos, todos tasados en 5.200 ducados de plata. $35.200^{34}$.

En $1686^{35}$ se ordenó y modificó este texto con la siguiente precisión "Seis Bufetes de Marmol [...] los dos bufetes son de blanco y negro con diferentes Istorias; y los otro (sic) quatro yguales con dhos lazos". Y en 1701 consta $^{36}$ :

${ }^{29}$ El dormitorio y piezas adyacentes de vestir, el retiradizo y, sobre todo, en 1636, la pieza de las bóvedas donde el rey se retiraba a descansar después de comer, decorada con las Poesías de Tiziano, debían de ser la parte verdaderamente reservada.

${ }^{30}$ Carlo Cesare Malvasia, Felsina Pittrice. Vita de 'pittori bolognesi, Bolonia, Per l'Erede di Domenico Barbieri, 1678, t. II, p. 409. Alude al episodio de Angelo Michele Colonna, "que passando una tal sera per una stanza ouè el Re stava facendo il rescritto a molte memoriali, interrogato da S. Maestà oue andasse, e perche non fosse al travaglio, le rispondesse, andarsene per esser la calce troppo molle".

31 Gloria Martínez Leiva y Ángel Rodríguez Rebollo, Qvadros y otras cosas que tiene Sv Magestad Felipe IV en este Alcázar de Madrid, año de 1636, Madrid, Fundación Universitaria Española, 2007, p. 56.

32 Inv. 1686, p. 298.

33 Inv. 1666, p. 294.

${ }^{34}$ La cifra de la tasación, 5.200 ducados, equivale a 57.200 reales y no a 35.200 reales que se llevan a la suma, que implican una rebaja de 22.000 reales. En el inventario de 1666 no es raro en el caso de muebles en que las cifras llevadas a las sumas no coinciden con los valores de la tasación, como en este caso y como ocurrirá también con los espejos que acompañaban a estos bufetes. En ambas partidas, se redujo la valoración de los tasadores. En otros, en cambio, se aumentó, como en el bufete de don Rodrigo Calderón de las bóvedas, en 23.100 reales más.

35 Inv. 1686, pp. 298-299.

36 Inv. 1701, p. 155. 


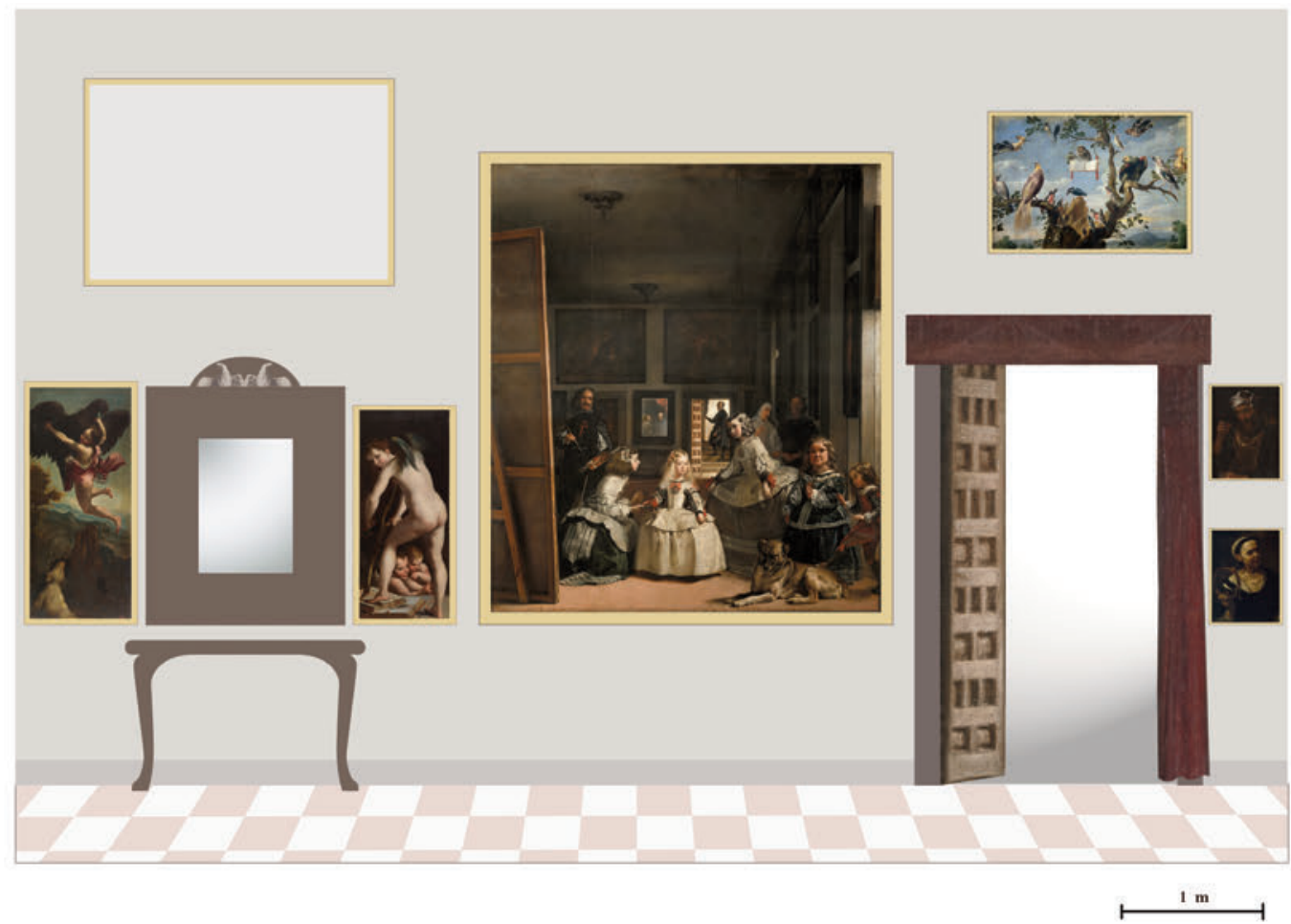

Fig. 4 Pared del pasillo del despacho de verano en el Alcázar con las pinturas 22-27 y 33 (Reconstrucción del autor).

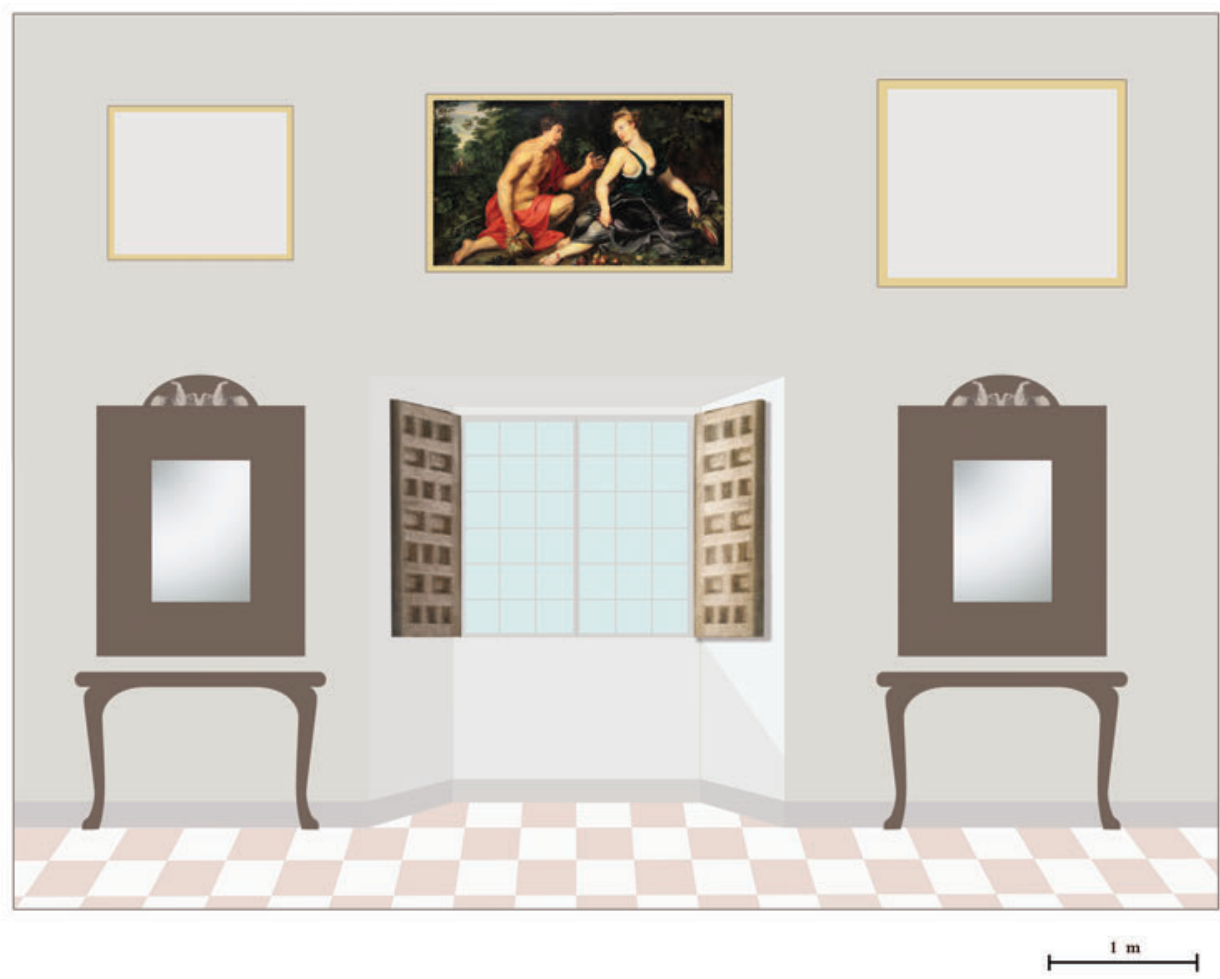

Fig. 5 Pared del cierzo del despacho de verano en el Alcázar con las pinturas 28-30 (Reconstrucción del autor). 
Quattro Buffetes de seis pies de largo y tres de ancho de mármol de Genova embutidos de pastta de diferentes lavores y Colores y se ttasaron por el dicho Marmolista en quattrocientos Doblones a ciento cada uno. 400. Yttem Ottros Dos Bufetes del mismo Mármol y tamaño embutidos de mármol negro y gravados Unas histtorias tassados en quattrocientos Doblones a doscienttos cada vno. $400^{37}$.

En resumen, el inventario de 1686 pone de relieve que los seis tableros no eran iguales, pues dos llevaban historias y otros cuatro eran más simples, adornados con lazos, lo que confirman las tasaciones de 1701, que evaluaron los historiados al doble que los otros. En 1773, el inventario realizado por Felipe de Castro describe lo que quedaba de estos bufetes como tres mesas de mármol blanco embutidas de escayola y otras dos embutidas de jaspes de distintos colores y escayola que tenían grabado "en la una el triunfo de un Emperador y en otra Apolo con las Horas"38.

Los espejos fueron inventariados en $1666^{39}$ de la siguiente manera: "Siete espejos grandes de zinco quartas de alto las lunas y más de tres de ancho con molduras de evano con faxas de espejos en los frisos guarnecidas de molduras ondeadas y dibididas de listas de Bronze dorado, caladas de labores, vale cada uno a 800 ducados de plata. $52.800^{\prime 40}$. Así se repitió en $1686^{41}$, pero en $1701^{42}$ se enriqueció esencialmente la descripción:

Ytten siette Espexos Yguales de dos varas y quarta de alto y cinco pies de ancho las lunas de en medio de quatro quartas y media de alto y tres quartas y dos dedos de ancho con sus adornos de cristales azogados y molduras ondeadas con siete hórdenes de moldura y quatro listas de bronce con dos Aguilas cada uno, también de bronce, tasados los cristales de cada Expejo a veinte y quatro Doblones por el vidriero y el Marco que es de ébano y los canttos de palosantto a quinienttos ducados; y las listas y águilas de cada Vno a mil y cinquenta reales de plata por el ebanista y plateros, que ttodo ymportta reduzidos los Doblones y platta a vellón cinquenta y nuebe mil seiscientos y cinco reales ${ }^{43}$.

Comparemos estos espejos con los del salón según el inventario de $1701^{44}$, toda vez que no aparecen en el inventario de 1666 y que en $1686^{45}$ no fueron tasados. La medida de las lunas del salón era de cinco cuartas menos cuatro dedos de alto por tres cuartas y cuatro dedos de ancho y las del despacho cuatro cuartas y media de alto por tres cuartas y dos dedos de ancho, casi iguales por tanto. El vidriero apreció alguna diferencia en la calidad de las lunas, pues tasó cada una de las del despacho en 24 doblones (1440 reales) y del salón en 20 doblones (1200 reales). Las tasaciones favorecieron con notable diferencia los marcos de ébano y palosanto del despacho con su adorno esplendoroso de cristales azogados y siete órdenes

37 Computado el doblón a 60 reales como era común en este momento, el valor de tasación, 800 doblones, equivalía a 48.000 reales, cifra más próxima a los 57.200 reales en que se tasaron en 1666 que a la cifra de 35.200 que se llevó a la suma.

38 Reconocimiento original de estatuas, bustos y otras cosas... Archivo General de Palacio, Sec. Reinado de Carlos III, leg. 2021.

39 Inv. 1666, p. 294.

40 Los 800 ducados, multiplicados por 7, equivalen a 5.600 ducados o 61.600 reales. Los 52.800 reales que se llevan a la suma equivalen a 4.800 ducados, que corresponde al valor de seis espejos.

41 Inv. 1686, p. 298.

42 Inv. 1701, p. 155

43 Es la suma exacta de las tasaciones de lunas, marcos y bronces de siete espejos, 10.080 reales de las lunas, 38.500 los marcos de madera y 11.025 las guarniciones de bronce con el premio de la conversión de plata al vellón del 50 por ciento.

44 "Yttem Ocho Espexos Yguales las Lunas de Cinco quarttas menos quatro dedos de alto y tres quartas Y quatro dedos de ancho con marcos de ebano de Porttugal y Unas empresas de Bronze dorado con Una Aguila Cada Espexo del mismo bronze dorado que mantienen y abrazan dichos Expejos tasadas las lunas por Balentín del Sol Uidriero a Veinte Doblones Cada Vna; Y por los marcos por Manuel Fernández Carrillo ebanista a treintta doblones Cada Uno y el Adorno de empresas Aguila y tarjettas por los dichos Alberto de Aranda y Mathías Vallejo a Zientto y Cinquentta doblones Cada Adorno que todo montta Un mill y Seiscientos Doblones. 1.600" (Inv. 1701, pp. 129-130).

45 "Ocho espejos las lunas de a una vara de alto y tres quartas de ancho con Marcos de Palosanto y unas empresas de Bronce dorado con una Aguila cada espejo del mismo Bronce dorado que mantienen y abrazan dhos Espejos" (Inv. 1686, p. 45). 
de molduras. Se tasaron individualmente en 500 ducados o 5.500 reales, en tanto que los marcos del Salón, hechos en España por Jan Wijnberg, se evaluaron en 30 doblones, equivalentes a 1.800 reales. Por el contrario, la guarnición en bronce de los marcos del despacho, cuatro listas caladas y un remate de águilas, que se tasaron individualmente en 1.050 reales de plata (equivalentes con el premio del 50 por ciento a 1575 reales de vellón), 11.025 reales en total, debía de ser mucho más ligera que la del salón, águilas con cabezas ladeadas y alas y garras que abrazaban los espejos, además de unas empresas de Júpiter y unas tarjetas en los marcos, todo valorado en 150 doblones, 9.000 reales de vellón cada uno y 72.000 reales en total; esta diferencia de valor no prejuzga la calidad del trabajo en bronce, pues entendemos que es debida a la cantidad de metal y mano de obra empleados en la labor, además de incluir un espejo más. La suma final que se lleva al inventario por los espejos del salón es de 1.600 doblones, esto es, 96.000 reales, frente a los 59.605 reales de los del despacho.

La valoración de los bufetes y espejos del despacho desciende considerablemente desde 1666 a 1701: sumaron las tasaciones conjuntas del primer inventario 118.800 reales aunque la cifra llevada a la suma fuera de 88.000 reales, y los mencionados 59.605 reales en la segunda. Por el contrario, las Meninas, que habían sido tasadas en 1666 en 1.500 ducados, equivalentes a 16.500 reales, se valoraron en 1701 en 10.000 doblones o 600.000 reales de vellón. Esta enorme subida es una señal de que el cuadro había adquirido a lo largo de estos 35 años la consideración de obra cumbre de Velázquez y una fama entre las pinturas de la colección real solo comparable a la del Pasmo de Rafael, evaluado en la misma cantidad.

No se ha hallado documentación segura en torno a estos muebles. El inventario de 1666 dice que el mármol de los bufetes era de Génova, lo que se repite en 1701, pero no se ha de dar por segura esta identificación. Marías los relacionó con la noticia de Jerónimo de Barrionuevo en su carta CXXX, de 25 de marzo de 1656, sobre un envío del conde de Castrillo, virrey de Nápoles (1653-1660) para Felipe IV, que describió así: "es un pasmo, entre otras cosas, seis bufetes de pórfido con piedras engastadas en ellos, de mucho precio y estimación, y otros seis espejos de dos varas y más de alto y vara y media de ancho, cuyas guarniciones, así de los bufetes como de ellos, no tienen precio"46. Las fajas de cristales azogados con superpuestos de bronce calado delatan el origen italiano de estos muebles. Barrionuevo pudo confundir el material de los bufetes, porque los engastes de piedras eran habituales en el mármol y no en el pórfido.

Un aspecto destacable es que en 1701 se indique que había “dos águilas en cada uno". No parece que se añadieran después de su llegada, pues las medidas de Barrionuevo son casi iguales a las de este inventario. Pero el hecho de que se citen tardíamente, el precio relativamente pequeño de la tasación del bronce de estos espejos y nuestro cálculo sobre su posible tamaño ${ }^{47}$ las aleja definitivamente de la enorme presencia que tenía el adorno aguileño de los espejos del Salón. Su insignificancia no impide que contuvieran una alusión a los Habsburgos, el común apellido de la pareja real.

La perplejidad surge cuando los inventarios hablan de seis bufetes y siete espejos, que, según se lee en 1701 , eran iguales, pues el número de espejos choca con la noticia sobre su supuesto origen. Estos muebles no debieron de ser fruto de una iniciativa de Castrillo -aunque pudiera regalarlos-, sino de un encargo del monarca según pautas de Velázquez. Uno de los bufetes llevaba representado a Apolo, una casualidad sospechosa atendido el asunto que luego se pintaría en el techo. Recordemos también que a la muerte del pintor se anotó entre los bienes del rey que tenía en su poder, lo siguiente: "En un arca se allaron los

46 Fernando Marías, "Las Meninas de Velázquez, del despacho de Felipe IV al cenador de Carlos III”, en Velázquez y Calderón: dos genios de Europa: IV Centenario, 1599-1600, Madrid, Real Academia de la Historia, 1999-2000, pp. 157-177, en especial, 157-159. Puso en relación la tasación de las Meninas en 1666 con los espejos y bufetes del Despacho para señalar que la de éstos era cinco veces mayor que el precio de la pintura.

47 En anchura, el marco medía en total cinco pies $(140 \mathrm{~cm})$ y la luna tres cuartas y dos dedos $(67 \mathrm{~cm})$. La diferencia, unos $73 \mathrm{~cm}$, sería la anchura del marco, sin duda igual por los cuatro lados. Como el largo total del espejo era dos varas y cuarta $(188 \mathrm{~cm})$ y el de la luna cuatro cuartas y media $(94 \mathrm{~cm})$, la diferencia de $94 \mathrm{~cm}$ se repartiría entre el marco, de $73 \mathrm{~cm}$, y las águilas, unos $21 \mathrm{~cm}$. 
cordones con borlas que vinieron de Ytalia con los espejos que embió el conde de Castrillo"48. No se menciona que fuera regalo del virrey sino un envío, y parece extraño que incluyera unos cordones para las cortinas si no hubo un encargo previo. Ese séptimo espejo pudo ser un modelo enviado para la aprobación, con lo que la hipótesis del encargo a Castrillo ganaría fuerza, pero también pudo hacerse posteriormente, una vez que el pintor vio que lo precisaba para completar su plan.

La disposición de los muebles era diferente en el despacho y en el salón. En éste, los espejos se disponían de forma pareada sobre cuatro de los bufetes -que medían tres varas de largo $(250 \mathrm{~cm})-$ mientras los otros dos, colocados entre las tres grandes ventanas de la fachada, llevaban encima cuadros. Los bufetes del despacho medían dos varas $(167 \mathrm{~cm})$ de largo y llevaban encima un espejo cuya anchura era cinco pies $(140 \mathrm{~cm})$ y dos varas y cuarta $(188 \mathrm{~cm})$ de alto. Si en el salón había dos bufetes sin espejo, aquí había un espejo sin bufete. A pesar de esta diversidad, es innegable la semejanza.

El despacho de verano era, por tanto, el único lugar en el Alcázar que presentaba un conjunto semejante al del salón, la pieza de mayor representación de todo el palacio. El parecido se acentúa si incluimos las pinturas de Velázquez hechas a propósito para ambas estancias y la pintura de las bóvedas por Angelo Michele Colonna y Agostino Mitelli. No es dudoso, por tanto, que el despacho de verano fuera, junto con el salón y la Pieza Ochavada, el objeto máximo de los desvelos del sevillano en su labor de decorador.

Aunque Velázquez se ocupaba del cuarto de verano desde 1645, el proyecto definitivo del despacho debió de tomar forma tras su vuelta de Roma y tardaría algún tiempo en poder llevarse a término. La pieza clave que iba a dar sentido a toda la invención decorativa sería las propias Meninas, cuya elaboración se data en 1656 aunque su concepción fuera algo anterior. Esta pintura determinó una transformación radical del aspecto del despacho de verano.

Nada se conoce sobre la forma y tiempo en que el sevillano gestó esta pintura, claramente muy meditada. Descartamos totalmente que el cuadro fuera una idea de Felipe IV. La idea fue de Velázquez, que, sin duda, hubo de pedir licencia para pintar una escena donde quedaran reflejados los reyes -aunque fuera en el espejoy, sobre todo, donde se incluyera a sí mismo con una presencia tan relevante. Velázquez conocía bien la predilección del monarca por la menor de sus hijas, y juzgó acertadamente que le sería grato aliviar las horas tediosas del trabajo en el despacho con la vista de Margarita en un retrato no común, en una escena sin aparato, plenamente cotidiana, de la niña rodeada de sus servidores habituales ${ }^{49}$. Este sería el pretexto utilizado por el pintor para obtener el beneplácito real a su proyecto. Quizá el sevillano tuvo alguna mayor dificultad para que se le permitiera retratarse dentro del cuadro, pero vencería la resistencia invocando los precedentes de Tiziano y otros semejantes. El mensaje que deseaba enviar a la posteridad pudo hacerlo suyo Felipe IV con facilidad, pues era gran admirador de la Pintura. Velázquez, que era el aposentador mayor de Palacio, estaba allí pintando a los reyes y declarando con ello la grandeza del arte de la Pintura. El rey trabajaba en el despacho y el pintor en el cuadro, uno al lado del otro, en diferentes pero dignísimos trabajos. Sin duda el cuadro quedó colocado de forma que el rey lo veía constantemente desde su mesa al levantar la vista de los papeles. Desde la tela, el pintor requeriría a la regia persona para que no olvidara su anhelo de obtener la merced esperada, el hábito de la orden de Santiago. Un atrevimiento que el rey únicamente podía admitir viniendo de Velázquez.

El resto de la decoración del despacho debió de ser ideada totalmente por Velázquez, sin perjuicio de su consulta al rey. Carlo Cesare Malvasia da un temprano testimonio del interés del rey por esta habitación, cuan-

48 Vid. José Manuel Pita Andrade (dir.) y Ángel Aterido Fernández (ed.), Corpvs velazqueño, t. I, p. Madrid, Ministerio de Educación, Cultura y Deporte, 2000, p. 467.

49 MARÍAS, 1995, pp. 249-252, se refirió a un retrato colectivo. Lo era en cuanto a género, pero su carácter y finalidad eran muy diferentes de los retratos colectivos de flamencos y holandeses. Carl Justi, Velazquez und sein Jahrhundert, Bonn, Cohen, 1888 (ed. Madrid, Istmo, 1999), p. 428, señaló paralelos con otro retrato colectivo ambientado de Velázquez en la Lección de justar de Baltasar Carlos (colección particular británica). Los hay en la preeminencia del personaje central, la reverencia del Condeduque, la presencia de dos enanos y otros servidores del palacio, además de que los reyes se hallan en la lejanía, aquí en un balcón. 
do dice que Colonna y Mitelli, apenas llegar y probar su maestría en el Buen Retiro, "por orden del mismo rey, pintaron las bóvedas de tres cámaras del cuarto real, la primera con la caída del soberbio Faetón, la segunda con la Aurora y la tercera con la Noche" ${ }^{50}$. Hicieron primero el despacho, aunque fuera el último en el orden de las ideas. Sobre la dirección de los asuntos artísticos, la verdad sale a relucir cuando narra que, no habiendo gustado a Velázquez el diseño de los italianos para la bóveda del salón de los espejos, menos aún había de complacer a su majestad "que todo se lo encomendaba"51. Queda claro de dónde partían las órdenes.

Corresponde ahora examinar las 32 pinturas elegidas por Velázquez para acompañar a las Meninas. Los inventarios de 1666, 1686 y 1701 describen las siguientes ${ }^{52}$ :

1. Festoncito de flores. Anónimo. 28,3 x 83,5 cm $\mathrm{cm}^{53}$. Paradero desconocido.

2. Dama veneciana ${ }^{54}$. Domenico Tintoretto, Museo del Prado, P00383. 77 x $65 \mathrm{~cm}^{55}$.

3-8. Seis Naturalezas muertas ${ }^{56}$. Alexander Adriaenssen, cuatro en el Museo del Prado, P01341 al P01344, 60 x $91 \mathrm{~cm}$. Las dos restantes, Museo del Ermitage de San Petersburgo, GE-6151 y GE-7282, 59,5 x $91,5 \mathrm{~cm}$ y $57,5 \times 86,5 \mathrm{~cm}^{57}$.

9. Flora $^{58}$. Jan Brueghel el Mozo. Museo del Prado, P01675, actualmente 167 x $95 \mathrm{~cm}^{59}$.

10. Bodegón. Frans Snyders. 208 x $250 \mathrm{~cm}^{60}$. Paradero desconocido.

11. Niños con flores y frutas. Juan van der Hamen. 208 x 83,5 cm $\mathrm{cm}^{61}$. Paradero desconocido.

12. Cupido $^{62}$. Guido Reni, Museo del Prado, P00150, 101 x 88 cm.

50 Carlo Cesare Malvasia, Felsina Pittrice. Vita de 'pittori bolognesi, Bolonia, Barbieri, 1678. t. IV, p. 407: “que ben tosto furono allogate loro le volte di tre camere del Quarto Reale in città; in una rappresentandosi, per ordine dello stesso Re, la caduta del superbo Fetonte, nella seconda l'Aurora, en ella terza la Notte, cha tanto furono lodate, e tanto piacquero a Sua Maestà, que ordinó anche la sala contigua lunga presso a cinquenta piedi, e larga ventotto".

51 Ibidem, p 408: "Dovevano nel mezzo pingere una Pandora e n'avean fatto un compito disegno, che non piacendo a Diego Velasco, tanto meno poteva esser gradito a Sua Maestà, che tutto a lui diferiva".

52 Conservamos el orden de registro del inventario de 1666 pero la numeración es nuestra a efectos de utilizarla en la reconstrucción. Las notas recogen el registro de ese año. Los inventarios de 1686 y 1701 conservan en general las medidas, asuntos y autorías, pero señalamos las diferencias existentes. Cuando las pinturas se conservan, se citan las atribuciones actuales, así como las medidas, y si no existen, se transcriben las del inventario traducidas a medidas actuales. La primera cifra de la medida corresponde al alto y la segunda al ancho.

53 "Un festoncico de flores, que tiene de largo una bara y una terzia de ancho, con marco de talla dorado, tasado en trezientos y treynta reales de plata. 330 ".

54 "Otra pintura, de una bara de alto, con marco de talla, que es un retrato de beneziana, de mano de Tintoreto, tasado en cinquenta ducados de plata. 550".

55 Identificación en Inv. 1666, p. 269.

56 " $[6$, el uno desclavado]. Otra pintura, de bara y quarta de largo y de ancho tres quartas, tasada en quarenta ducados de plata, que es un bodegón de mano de un flamenco. Y otros cinco bodegonzillos, del mismo tamaño y mano, con sus marcos de talla, tasados cada uno en quarenta ducados de plata, que importan dos mil seiscientos y quarenta reales de plata. 2640".

57 Identificación en Inv. 1666, pp. 274-276.

58 "Otra pintura, de dos baras de alto y tres quartas de ancho, de mano de Rubenes, que es una Ninfa con flores en la mano, tasada en cinquenta ducados de plata. 550".

59 Atribución de Matías DíAz PAdrón, El lienzo de Vertumno y Pomona de Rubens y los cuartos bajos de verano del Alcázar de Madrid, Madrid, El Viso, 2009, pp. 74-75; antes taller de Rubens.

60 "Otra pintura, de tres baras de largo y dos y media de ancho, de un bodegón, de mano de Esneiles, con marco dorado y tallado, en trezientos ducados de plata. 3.300".

61 "Otra pintura, de dos baras y media de alto y de ancho una bara, de unos niños, de mano de Juan Balesio, con su marco tallado, tasado en quinientos cinquenta reales. 550”. Identificación en Inv. 1666.

62 "Una pintura, de bara de alto y tres quartas de ancho, de un cupido, de mano del Guido Bolonés, con su marco tallado y dorado, en cien ducados de plata. 1.100". 
13. Amor desinteresado ${ }^{63}$. Guercino, Museo del Prado, P00205, 99 x $75 \mathrm{~cm}$.

14-15. Dos Floreros $^{64}$. Jan Brueghel el Viejo, Museo del Prado, P01449 y P01450, 181 x 70 cm$^{65}$.

16-19. Cuatro Floreros ${ }^{66}$. Mario Nuzzi “dei Fiori”. Dos Museo del Prado, P01051 y P00253, 112 x 71 cm y 113,5 x 71,5 cm. Los otros dos en paradero desconocido ${ }^{67}$.

20-21. Dos Filósofos. José de Ribera, 63 x $42 \mathrm{~cm}^{68}$. Paradero desconocido.

22. Las Meninas ${ }^{69}$. Diego Velázquez, Museo del Prado, P01174, 318 x $276 \mathrm{~cm}$.

23. Cupido labrando su arco $^{70}$. Copia de Parmigianino, Museo del Prado, P00281, 148 x 65 cm.

24. Paisaje. Anónimo italiano. Tal vez Museo del Prado, P06313, 146 x 219 cm¹.

25. Rapto de Ganímedes ${ }^{72}$. Copia de Correggio por Eugenio Cajés, Museo del Prado, P00119, 175 x $72 \mathrm{~cm}$.

26-27. Viejo con taza ${ }^{73}$. Vieja con sonaja ${ }^{74}$. José de Ribera. El primero Museo del Greco, CE00038, 66 x $49 \mathrm{~cm}$, y el segundo Museo del Prado, P00880, 80 x $62 \mathrm{~cm}$.

28. Vertumno y Pomona ${ }^{75}$. Rubens, Colección particular madrileña, 116 x $186,5 \mathrm{~cm}^{76}$.

29. Amarilis y Mirtilo. Van Dyck, $104 \times 125 \mathrm{~cm}^{77}$. Paradero desconocido ${ }^{78}$.

30. Reinaldo y Armida. Van Dyck, $167 \mathrm{~cm}^{79}$. Paradero desconocido ${ }^{80}$.

63 "Un cupido del mismo tamaño de mano del Guarchino tasado en mill y cien reales de plata. 1.100".

64 "Una jarra de flores de dos baras de alto con su marco de talla en trezientos y treynta reales. 330". "Otra del mismo tamaño en trecientos y treinta reales. 330".

65 Identificación en Inv. 1666, pp. 280-281; en los inventarios de 1686 y 1701 se atribuían a Mario.

66 "Dos jarras, digo quatro, de bara y quarta de alto y tres quartas de ancho de mano del Mario con sus marcos de talla dorados tasadas a quarenta ducados cada una que importan mill setezientos y sesenta reales de plata. 1.760".

67 Identificación en Inv. 1666, pp. 281-282.

68 "Dos cabezas de tres quartas de alto y media bara de ancho con sus marcos de talla que son dos filósofos de mano de Jusepe de Ribera tasados en cinquenta ducados cada uno. 1.100".

69 "Una pintura de quatro baras y media de alto y tres y media de ancho con su marco de talla dorado retratando a la Señora Enperatriz con sus damas y una enana de mano de Diego Belazquez en mil y quinientos ducados de plata. 16500”.

70 "Otra pintura de dos baras de alto y dos tercias de ancho de un cupido de mano del Corezo con su marco de talla dorado tasado en trezientos ducados de plata. 3.300".

71 "Otra pintura de tres baras de largo y siete quartas de ancho de un país ytaliano en ciento y cinquenta ducados de plata con su marco tallado dorado. 1.650".

72 "Otra pintura de dos baras de alto de un Ganimedes de mano de Coreço con su marco de talla dorado en docientos y zinquenta ducados de plata. 2.750". En 1701 se señala "pareze Copia del Corezo".

73 "Dos cabezas de tres quartas de alto y media bara de ancho con sus marcos de talla que son dos filosofos de mano de Jusepe de Rivera tasadas en cinquenta ducados cada uno. 1.100". Los inventarios de 1686 y 1701 señalan "uno con una taza en la mano, y otra con unas Sonajas". Proponemos la identificación del hombre con taza en la mano con la pintura del Museo del Greco, que coincide en el asunto, postura contrapuesta a la vieja con sonaja y medidas originales del inventario, que no tiene su pareja, ampliada antes de 1734 con tres tiras. Prueba definitiva es que esta pintura lleva al dorso una inscripción antigua que dice "E.bn March", que sería la base de la antigua atribución a este pintor valenciano de la mujer con sonajas.

74 Inv. 1666, p. 288.

75 "Otra pintura de tres baras de largo y bara y media de alto de Pomona y Bertulo de mano de Rubenes en ciento y cinquenta ducados de plata. 1.650".

76 DíAZ PADRÓN, 2009.

77 "Otra pintura de bara y media de largo y bara y quarta de ancho de un bacanario de unas ninfas de mano de Bandic tasado en doscientos y zinquenta ducados con su marco de talla. 2.750".

78 Asunto identificado por Díaz PAdRón, p. 84.

79 "Otra pintura de dos baras de alto de una fabula de mano de Bandic con su marco de talla tasada en duzientos y zinquenta ducados 2.750”. En 1701 se cambió el alto por ancho.

${ }^{80}$ Asunto identificado por DíAz PAdrón, p. 84. 
31. Muchacha con una rosa en la mano ${ }^{81}$. Guido Reni, Museo del Prado, P00218, 81 x 62 cm.

32. Damas y hombres venecianos. Atribuido a Antonio Badile, Museo del Prado (depositado en el Museo del Greco), P00450, 156 x $107 \mathrm{~cm}^{82}$.

\section{Concierto de aves ${ }^{83}$. Frans Snyders, Museo del Prado, P01758, 98 x $137 \mathrm{~cm}$.}

Si tuviéramos que destacar alguna característica de este conjunto de pinturas, además de la completa ausencia de asuntos religiosos, sería la reciente llegada al palacio de la mayoría de ellas, sin olvidar las propias Meninas y el restante adorno. Sólo siete se localizan en el Alcázar en 1636, aunque en otros lugares, y debieron trasladarse allí porque convenía a la idea del pintor ${ }^{84}$. Por el contrario, hay seguridad de que diez ingresaron en la colección real en fechas muy cercanas a $1656^{85}$ y el resto también en momentos recientes ${ }^{86}$. Conviene recordar el ansia de Felipe IV por ampliar su colección de pintura y no es extraño que Velázquez hiciera una selección entre las últimas adquisiciones, que debió de orientarse por criterios de calidad primero, pero también por la conveniencia iconográfica y de tamaño ${ }^{87}$. Después de la muerte del sevillano no parece que se hicieran cambios importantes, a diferencia de lo que sucedió en el antedespacho $^{88}$ o el aposento de las bóvedas donde el rey despachaba en los caniculares ${ }^{89}$, que se habían llenado de ejemplares llegados después de 1660 y, por tanto, habían perdido en 1666 el carácter que el sevillano había querido darles. En el despacho, el rey no hubiera consentido que se modificara el escenario que con tanto cuidado había preparado su pintor predilecto y que tenía para él un significado especial.

81 "Otra de tres quartas de alto y media bara de ancho de una caveza de mano de Guido Boloñes con una rosa en la mano en cinquenta ducados. 550".

82 "Otra pintura de dos baras de alto y bara y quarta de ancho de unas damas benezianas de mano de Pablo de Barona tasada en ciento y zinquenta ducados con su marco de talla. 1.750". Proponemos la identificación con la pintura de Badile del Museo del Greco por la coincidencia de medidas y asunto y porque fue maestro de Veronés. Jeffrey M. MÜLLER, Rubens: the artist as collector, Princeton, University Press, 1989, p. 98, identificó la partida del inventario con la pintura adquirida en la almoneda de Rubens en 1640 descrita como "una recién casada veneciana acompañada de sus parientes".

83 "Otra pintura de siete quartas de largo y bara y media de ancho con un tronco y muchos pajaros en el tasada en treynta ducados. 330". En 1686 y 1701 se añadió “de mano no conocida”.

${ }^{84}$ El cuadro de van der Hamen, los dos floreros de Brueghel, Vertumno y Pomona, el Concierto de aves, y las copias de Parmigianino y Correggio.

85 Son las seis naturalezas muertas de Adriaenssen legadas por el marqués de Leganés a Felipe IV en 1652, que los recibió antes de su fallecimiento, ocurrido en 1655 (José Juan PÉREz PRECIADO, "Los bodegones de Alexander Adriaenssen de la colección de Felipe IV y su primer poseedor", en In sapientia libertas: escritos en homenaje al profesor Alfonso E. Pérez Sánchez, Madrid, Fundación Universitaria Española, 2007, pp. 392-401); la pareja de Cupido de Reni y el Amor de Guercino, regalada por el cardenal Camillo Massimi a Felipe IV entre 1654 y 1655, cuando llegó a la Corte como nuncio (Lisa BEAVEN, "Reni's 'Cupid with a bow' and Guercino's 'Cupid spurning riches' in the Prado: a gift from Camillo Massimi to Philipp IV of Spain?”, The Burlington Magazine, vol. 142, $\mathrm{n}^{\mathrm{o}} 1168$ (2000), pp. 437-441); y Amarilis y Mirtilo y Reinaldo y Armida de Van Dyck, que vinieron de la almoneda de Carlos I de Inglaterra y fueron enviados por el conde de Fuensaldaña a don Luis Méndez de Haro para Felipe IV en 1656 (DíAz PADRón, p. 84).

${ }^{86}$ Las Damas y hombres venecianos vinieron de la almoneda de Rubens en 1640. Se ha propuesto que los dos -o cuatro- filósofos de Ribera, en realidad una serie incompleta de los cinco sentidos, fueran dádiva del duque de Medina de las Torres (Fernando BouzA, "De Rafael a Ribera y de Nápoles a Madrid. Nuevos inventarios de la colección Medina de las Torres-Stigliano (16411656)", Boletín del Museo del Prado, 45 (2009), pp. 44-71, p. 64). Tal vez algunas de las pinturas las adquiriera Velázquez en Italia, como la Dama de Domenico Tintoretto o la Muchacha de Reni, el paisaje italiano o los floreros de Mario. No se sabe cómo entraron en la colección real el festoncito, la Flora y el Bodegón.

87 Las medidas de los inventarios son casi siempre aproximadas, pues ya advierten los autores de que las solían medir sin descolgar y con marcos (AGP, Secc. Administrativa, leg. 768, exp. 14, in fine). El máximo exponente de ello es la medida en altura de las Meninas, 4 varas y media según los inventarios $(378 \mathrm{~cm})$ y actualmente $60 \mathrm{~cm}$ menor.

88 Tenía pinturas adquiridas a Serra di Cassano en 1664.

${ }^{89}$ Había diez retratos de la casa de Francia que habían llegado a Madrid después de 1660, que incluían un ejemplar de la reina María Teresa vestida a la moda francesa, además de 16 estatuillas de barro cocido de Juan Bautista Morelli, 1legado a la Corte tras morir Velázquez. 
Para la hipótesis que queremos formular respecto a la reconstrucción del despacho es clave fijar la situación de la mesa donde el rey despachaba. En nuestra opinión, la mesa estaba junto a la ventana de levante, algo esquinada hacia la pared del Cierzo, un lugar que recibía luz natural y desde el que el rey podía ver las dos puertas de la pieza. Otra colocación hubiera obligado al monarca a molestos giros para ver a los visitantes, que entrarían desde el antedespacho y saldrían por la puerta que daba al pasillo.

Dependiendo de lo anterior, la siguiente hipótesis se refiere al lugar donde se colgaron las Meninas. Desde la posición de la mesa que hemos propuesto, sólo había dos paredes que el monarca podía contemplar a placer: la que daba al pasillo y la que lindaba con el antedespacho. Las que tenían fachada al cierzo y a levante no hubieran facilitado la vista del cuadro desde el sillón real, y la primera tenía, además, una ventana en el centro que hubiera obligado a colocar las Meninas en una posición ladeada, poco digna en nuestra opinión. Los tasadores del despacho de 1666 entraron por la puerta que daba al antedespacho, y, en lo sustancial, parece que siguieron por la pared de levante desde la mesa del rey a la puerta del antedespacho, luego por la del pasillo en sentido contrario hasta finalizar en la del cierzo ${ }^{90}$. El orden del inventario nos lleva a señalar para las Meninas la parte central de la pared que daba al pasillo, una zona iluminada por la ventana con vistas a levante que quedaba enfrente. La posición era perfecta por estar constantemente en el punto de mira del rey sentado en su mesa y muy visible para los visitantes que entraban desde el antedespacho.

Observamos que no existe inconveniente para que cualquier pared pudiera alojar hasta dos bufetes, que tenían $167 \mathrm{~cm}$ de largo, pero la presencia de las Meninas, con su anchura de $276 \mathrm{~cm}$ frente a los 140 de los espejos, haría extraño colocar un bufete debajo y por tanto más de uno en la pared del pasillo. De este modo serían las paredes cortas las que tenían dos bufetes. La otra pared larga, enfrente de las Meninas, albergaría un bufete con su espejo y también el séptimo espejo, que no tenía bufete. Sin embargo, esta ausencia no se percibiría apenas por la proximidad de la mesa del rey, que tapaba esa zona del zócalo. La mesa del despacho era el séptimo bufete.

Las pinturas se disponían en una zona inferior en torno a los espejos y otra superior sobre ellos y los cuatro vanos, y ambas eran unidas por las Meninas. Díaz Padrón pensó que existía en el despacho un programa referido al amor y la belleza y Greub a la sucesión de Margarita al trono. Marías descartó que las pinturas crearan un programa iconográfico. Estamos de acuerdo en que son demasiado heterogéneas para que respondan a una sola línea argumental, pero se agrupan en varias direcciones significativas. Así, la pared lindante con el antedespacho, muy visible desde la mesa del soberano, estaba llena de piezas de caza y de manjares como los que le esperaban en la pieza de comer, tras cruzar el antedespacho. Las flores son también una constante; se acumulan en las paredes de levante y del mediodía y en el lado del cierzo había tres poesías abundantes en verdor ${ }^{91}$. Estas son escenas de enamorados y el Amor continúa presente en los recién casados de Badile y su cortejo y en los tres Cupidos y un Ganímedes. Los cuatro llamados filósofos eran quizá parte de una serie de los cinco sentidos -se conservan los correspondientes al Gusto y al Oído-, e incluso la pequeña Dama con la rosa podía aludir al Olfato. De lo que no cabe duda es que Velázquez buscó crear un ambiente amable, placentero, adecuado para aliviar el fatigoso trabajo de despacho.

Otra cuestión son las bóvedas pintadas con las tres conocidas alegorías en el cuarto nuevo. Para encadenarlas se aprovecharon las características de las tres piezas comunicadas entre sí, que llevaban desde la oscuridad del cuarto de comer -donde se pintó la Noche-, con una única ventana a levante muy esquinada y cercana a la crujía norte del palacio, a una pieza algo más iluminada, el antedespacho o la Aurora, y al final del recorrido, el despacho, la más luminosa, con dos ventanas de distinta orientación, donde se pintó a Apolo, Sol

\footnotetext{
$90 \mathrm{El}$ orden del inventario se iniciaría en la pared de la puerta por la que entraron los tasadores en 1666, que dividía el despacho y el antedespacho, y las Meninas ocupan la posición 22, lo que nos lleva a otra pared que no fuera la primera.

91 Amarilis y Mirtilo y Vertumno y Pomona hacen referencia concreta a las flores.
} 
y Día, rector de las Horas y Estaciones ${ }^{92}$. Se trata de una imagen tópica del barroco utilizada, por ejemplo, en la égloga pastoral compuesta en 1627 por Lope de Vega titulada La selva sin amor que se cantó a sv Magestad que Dios guarde en fiestas de su salud ${ }^{93}$. Si Apolo era Felipe, el efecto Febo se tradujo en las paredes en exuberantes naturalezas, pero no en mensajes políticos, a lo sumo alegóricos en los tableros de los bufetes con el triunfo del emperador, alusivo al de Felipe IV, y sobre todo con la escena de Apolo con las Horas, que simbolizaban, según la Teogonía de Hesíodo, las Leyes, la Justicia y la Paz, y los abundantes espejos, para poder decir que en el Príncipe, como un espejo, compone el pueblo sus acciones ${ }^{94}$.

A nuestro juicio, el interés de Velázquez no se centraba tanto en crear una iconografía coherente como en llenar la habitación de sorpresas barrocas. El espejo inmediato a la ventana a levante estaba enfrentado en parte a las Meninas. Debía reflejar la propia pintura, por lo que el rey podría ver desde su posición ladeada toda la pintura real y su imagen en el espejo a una distancia de más de ocho metros. Cuando el sol de la mañana entrara por esa ventana iluminando fuertemente la tela, se vería con claridad su parte central, donde estaba retratada la infanta, que, durante breves instantes sería en ese espejo la Aurora surgiendo en medio de un jardín. Las reglas de la reflexión permitían a Felipe IV contemplar desde su mesa a la que llamaba "famossa bufona" 95 y ésta a él ${ }^{96}$. Por el contrario, a la caída del sol, el séptimo espejo, al lado de la mesa del rey, recibiría una intensa luz a través de la ventana del cierzo, recordando el crepúsculo y el final del día. Apolo desde el techo y el Sol desde las ventanas del despacho, ayudado por los espejos, regían el discurrir diario de la jornada de trabajo de Felipe IV.

El engaño estaría sobre todo presente en el número de espejos. Los más observadores preguntarían la razón de que la pieza tuviera siete, un número impar que no parece encajar con los cánones de simetría de la época. Si imaginamos un espejo como los otros siete inserto en el centro de las Meninas obtenemos una sorprendente coincidencia, que en realidad no es tal: la luna encierra justo el retrato de cuerpo entero de Margarita, que incluso tiene a su izquierda una ventana -la puerta de Nieto- al modo de los retratos de aparato e imitando la cortina inventada sobre los reyes (fig. 6). Los demás espejos tienen cuadros a los lados: serían aquí las dos meninas, con lazos como flores y tonos blancos, rojos y negros, imitando los floreros de Brueghel, y sobre la infanta están los bustos de los reyes como los de las águilas, mayores si estuvieran en el mismo plano que Margarita, lo mismo que los dos cuadros superiores con asuntos apenas visibles de Mazo, imitando los dos floreros de Mario (fig. 7).

Si la observación seguía adelante, habiendo constatado el espectador que todo el cuadro de las Meninas hacía la función de octavo espejo de la estancia ${ }^{97}$, percibiría que lo que se ve parece reflejo y no visión gra-

92 El paso del tiempo de la juventud a la madurez se ve en Faetón como la infanta, más prudente, que se mira en el espejo de su padre Felipe IV-Apolo, el cuarteto de criados jóvenes y el de los entrados en años, y los tres Cupidos y Ganimedes con los cuatro Filósofos. El carro del Sol y las Horas están presentes también en el reloj del retrato de la infanta de 1659 de Viena, con copia en Budapest, según el texto de Palomino.

93 "Febo Español, la luz restituida,/ cándida más que en árboles Sabeos,/ oy amanece en almas y deseos/ por justos votos de su Fénix vida./ Sale de escura noche más hermosa/ la blanca Aurora a repartir colores,/nieve al jazmín y púrpura a la rosa:/ Assí Felipe dio rayos mayores,/ y amaneciendo su salud dichosa,/ los ojos almas y los campos flores" (Lope Félix de VeGA CARPIO, Lavrel de Apolo, Madrid, Juan González, 1630, fol. 104v).

94 Diego de SaAvedra Fajardo, Idea de un Príncipe Político Christiano representada en cien empresas, Múnich, Nicolao Enrico, 1640, empresa XXI.

95 Antonio Moreno Garrido y Miguel Ángel Gamonal Torres, Velázquez y la Familia Real a través de un epistolario de Felipe IV, Madrid, Fundación Universitaria Española, 1988. Con esta expresión se referirá a Margarita en la carta de 8 de julio de 1653 a la condesa de Paredes.

96 La raya del pelo y su adorno estarían como en los otros retratos de Velázquez de la Infanta, aunque en las Meninas cogía el búcaro correctamente con la derecha. Velázquez introdujo por eso otras ambigüedades, como la mirada de Margarita y la suya. Mientras que Mari Bárbola, Velasco, Ulloa, el guardadamas y Nieto miran al centro, es decir a Felipe IV o el visitante que han entrado en la estancia y contemplan el cuadro, la infanta y el pintor dirigen la vista a ese punto pero aún la tienen hacia su izquier$\mathrm{da}$, donde estaba sentado el rey en su mesa. Otro tanto ocurre en la imagen de las Meninas reflejada en el espejo real.

97 Igual que a través de la luna del espejo real se veía el despacho cuanto más se aproximase el espectador, en las Meninas se finge que al acercarse a mirar la "luna" donde está Margarita puede ver el resto del Cuarto del Príncipe. 


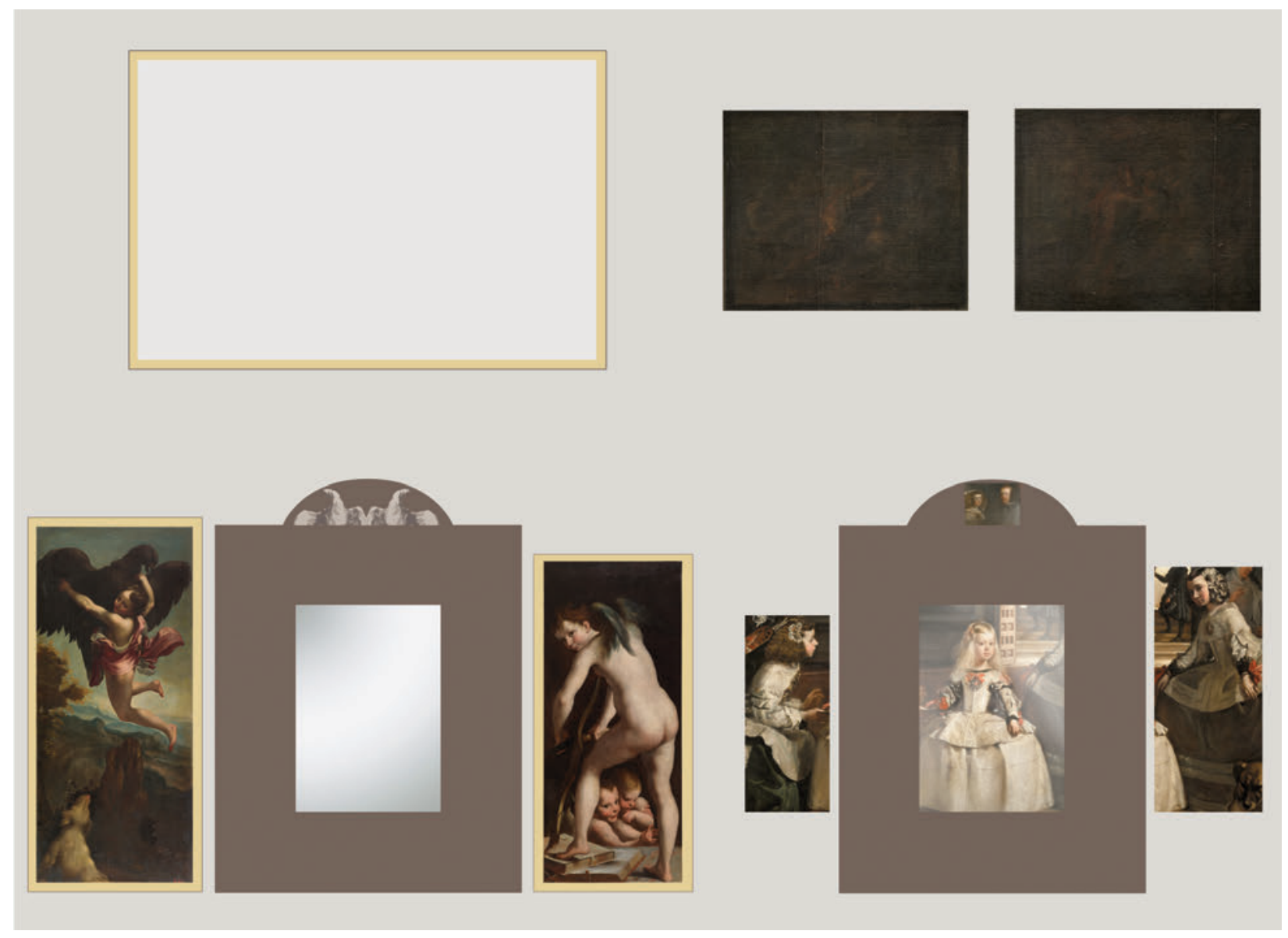

Fig. 6. Simulacro de las Meninas como espejo rodeado de pinturas en la pared del pasillo (Reconstrucción del autor).

cias a las características técnicas descritas por Palomino: la densidad aérea, la dificultad para reconocer el oscuro fondo y la profundidad de su perspectiva. Esta hace que se refleje el espejo real de la pared de levante en el espejo con su mesa que Velázquez había pintado en el fondo de su lienzo ${ }^{98}$, que se ha pensado que fueran también invención, aunque es posible que no lo fueran ${ }^{99}$. Si el espectador advertía que en el marco de ese espejo no había águilas, se le podría contestar que, en efecto, no las había fuera, pero que estaban dentro, Felipe IV y Mariana, cuyo símbolo como Habsburgos eran las águilas. Un paso más allá para el observador consciente de las paradojas visuales que encierran las Meninas era pensar que, al igual que en la pintura Velázquez utilizó el artificio del espejo para mostrar el doble retrato real que llevaba al lienzo -pese a la objeción de la excesiva altura, paliada por la cortina simulada-, en el despacho echó mano del mismo recurso para mostrar en el espejo real el lienzo ya no sobre el caballete, sino colocado, pues estaba acabado: las propias Meninas, adecuadas en altura y en anchura a lo que pintaba Velázquez ${ }^{100}$.

98 La reflexión no sería exacta, puesto que los espejos enfrentados están próximos pero no en una misma línea, pero en todo caso se reconocía el conjunto del espejo y sus pinturas de levante como correspondiente a las Meninas en la otra pared.

99 Extraña que en el cuarto del príncipe no hubiera muebles ni cuadros en el centro de esa pared y de su contraria. No se conocen inventarios de este cuarto hasta 1686 y el espejo y bufete que pinta Velázquez son muebles comunes de color negro.

$100 \mathrm{La}$ anchura no se puede determinar pues el lienzo está en perspectiva, pero como contenía el doble retrato real, podía medir los $276 \mathrm{~cm}$ de las Meninas. 

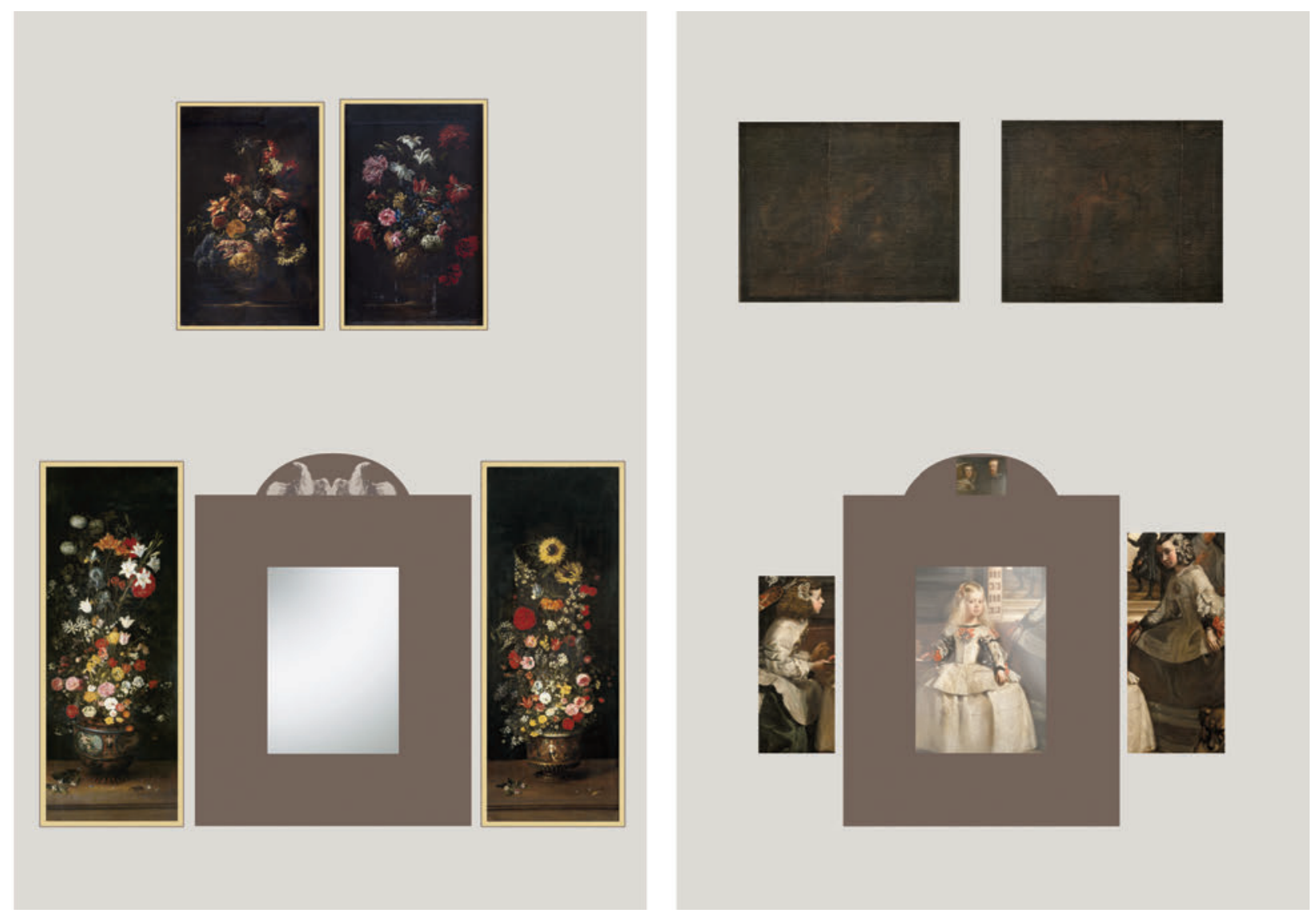

Fig. 7. Simulacro de las Meninas como espejo rodeado de pinturas enfrentado al espejo y pinturas de levante (Reconstrucción del autor).

Las dos paredes largas del cuarto articulan otra sugerencia especular, aunque invierte también derecha e izquierda: a dos filósofos en la esquina junto a la puerta del antedespacho correspondían otros dos en la esquina opuesta, y a dos cupidos al lado del espejo junto al rey otro Cupido y Ganímedes rodeando el espejo junto a las Meninas. Completan este juego visual las pinturas y elementos decorativos que doblan a los personajes de las Meninas. Los reyes repiten su presencia simbólica en las águilas de los espejos, Margarita en las pinturas de flores, los criados en los cuadros que colgaban en las paredes. Cuatro filósofos replican a los cuatro personajes de mayor edad como confirman los dos conservados con la taza y la sonaja, hombre y mujer en posiciones enfrentadas, como el guardadamas y Marcela de Ulloa "que hacen a lo historiado maravilloso efecto" según Palomino ${ }^{101}$. El joven Ganímedes está algo arrodillado como María Agustina Sarmiento y debajo el perro, y el adolescente Cupido "con un movimiento, y acción propicísima de hablar" como Isabel de Velasco (fig. 8). Vistas las Meninas en el espejo enfrentado, el Cupido niño de Reni recuerda al bufón Pertusato en el movimiento de piernas, domado por la paloma como este trata de dominar al perro; "su ferocidad en la figura, lo doméstico, y manso en el sufrimiento; pues cuando le retrataban se quedaba inmóvil en la acción, que le ponían". El Amor niño de Guercino suelta monedas de la bolsa de forma desinteresada, parodia de la bolsita con monedas que lleva la enana Mari Bárbola, interpretada como

101 En una inversión de caracteres similar a la de los bufones y los Amores, Ulloa y el guardadamas tienen composturas serias que contrastan con la despreocupación del borracho y la vieja con sonajas. 


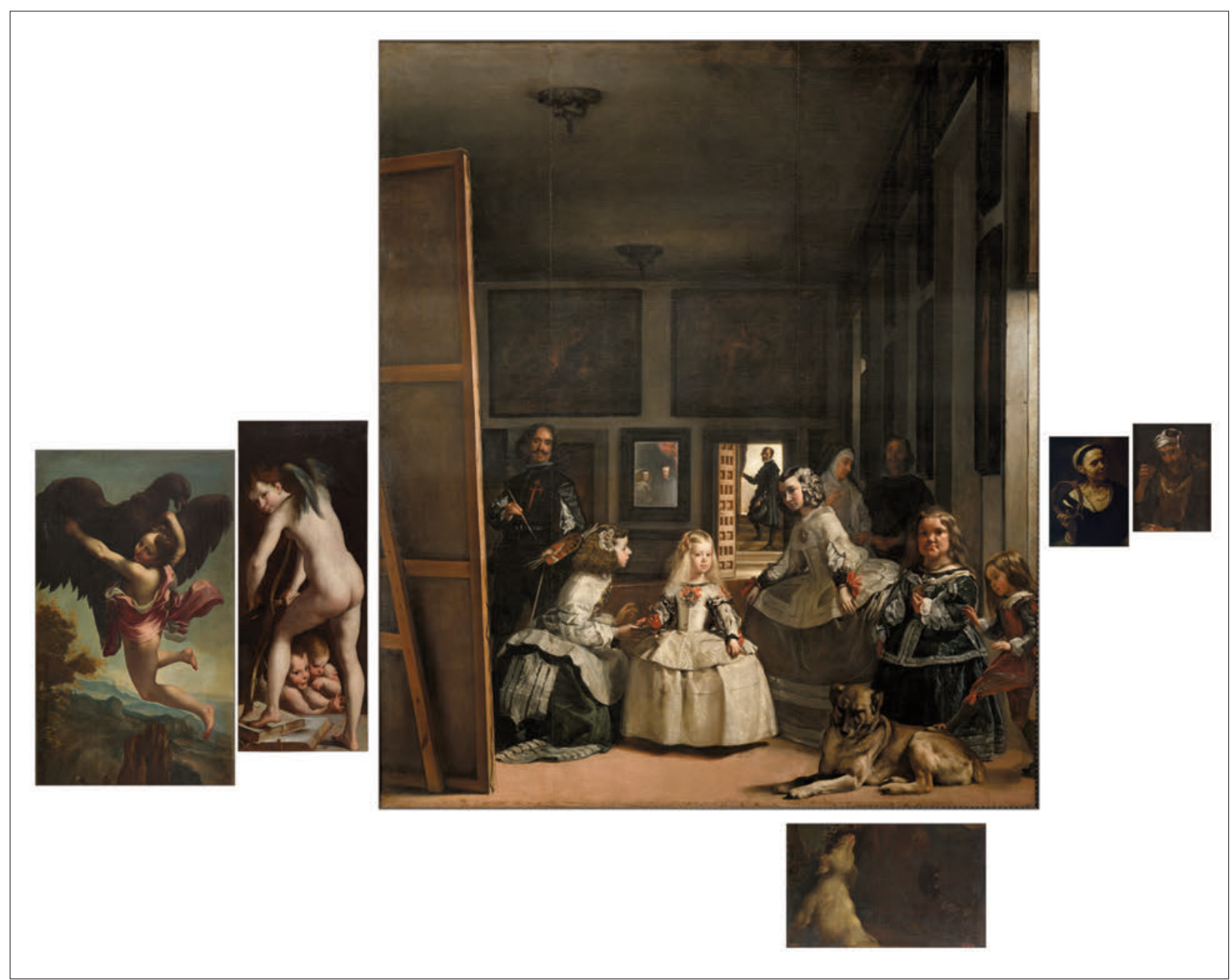

Fig. 8. Repetición simulada de cuatro criados de las Meninas en la pared del pasillo (Reconstrucción del autor).

señal de avaricia o codicia (fig. 9) ${ }^{102}$; los dos bufones son así caracteres invertidos respecto a los Cupidos, en lo que supone otro juego especular.

La mejor defensa de la pintura como arte liberal y de sus aspiraciones personales que podía hacer Velázquez era este derroche de ingenio en toda la decoración del despacho, culminada con un juego ilusorio de presencias creado a partir de unos espejos y las Meninas como uno de ellos. El pintor, con su enorme habilidad, imitó la realidad como sucede en un espejo, pero al igual que este no reproduce una imagen exacta - por sus inversiones- ni corpórea, esa imitación pictórica la superó además con su capacidad intelectual al transformarla igualmente hasta el engaño ${ }^{103}$. De nuevo, Palomino nos transmite la percepción de este logro en aquel siglo: "Y haviendo venido en estos tiempos Lucas Jordán, llegando a verla, preguntóle el Señor Carlos Segundo viéndole como atónito: ‘¿Qué os parece?’ Y dijo 'Señor, esta es la Teología de

102 En la parte superior había también parejas mitológicas como la de los reyes, flora, fauna y tres retratos con ocho personajes igualmente.

${ }^{103}$ No en vano, los juegos entre los espejos del Despacho producían una multiplicidad de imágenes reales y engañosas. Esas reflexiones múltiples tienen lugar también en el espejo real y el fingido de las Meninas y entre ambos, pues reproducían el cuadro y dentro del mismo otro espejo con otra pintura (el retrato de los reyes). 


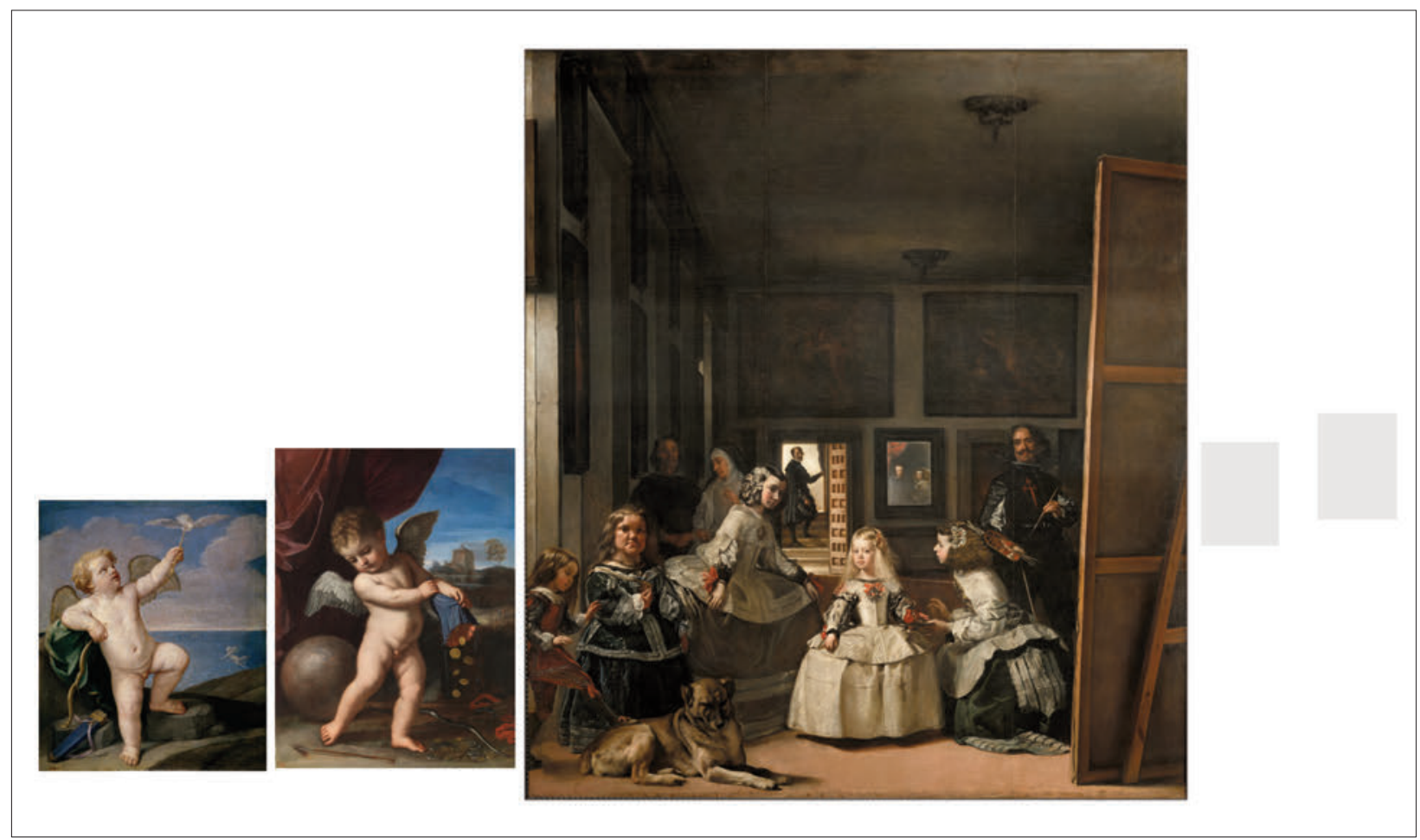

Fig. 9. Repetición simulada de cuatro criados de las Meninas en la pared de levante (Reconstrucción del autor).

la pintura': queriendo dar a entender, que así como la Teología es la superior de las Ciencias, así aquel cuadro era lo superior de la Pintura"104.

El despacho de verano, una creación maestra del barroco, llevaba en sí mismo el germen de su agotamiento por ser fruto de su momento y su circunstancia. Perduró mientras su mensaje vinculado a los Habsburgos fue apreciado. La llegada de los Borbones lo convirtió en un molesto testimonio de homenaje a los enemigos austriacos. En 1703, todos los cuadros, salvo las Meninas, se descolgaron y, junto con los bufetes, se entregaron a los encargados de decorar el nuevo Cuarto de la Reina. Sólo los ocho "espejos" quedaron en su lugar original, y de ellos sobrevivió uno solo, pues, afortunadamente, erró Palomino cuando vinculó la fama del pintor al retrato de Margarita.

JUAN MARÍA CRUZ YÁBAR es doctor en Historia del Arte por la universidad Complutense con la tesis Sebastián de Benavente (1619-1689) y el retablo cortesano de su época. Pertenece desde 2005 al Cuerpo Facultativo de Conservadores de Museos del Estado. Desde 2007 pertenece al departamento de Edad Moderna del Museo Arqueológico Nacional. Ha publicado una treintena de artículos en revistas especializadas y obras colectivas desde 2005, sobre arquitectura, retablos, escultura, pintura, dibujo, platería y tejidos de la Corte madrileña, Italia y Países Bajos, de los siglos XVI y XVII. Ha redactado alrededor de medio centenar de fichas en catálogos de exposiciones, y pronunciado varias conferencias sobre sus trabajos.

Email: juan.cruz@mecd.es

104 Su rival Claudio Coello repitió el juego de las Meninas como espejo que separa espacio real y virtual con su cuadro de la Sagrada Forma de la sacristía del Escorial, pero superó también la mera imitación especular con una profunda elaboración que conduce al espectador a la reflexión. 